\title{
Quasi-Biennial Oscillations in Atmospheric Ozone from the Chemistry-Climate Model and Ozone Reanalysis
}

\author{
Vazhathottathil Madhu',2, Kengo Sudo' ${ }^{1}$ \\ ${ }^{1}$ Graduate School of Environmental Studies, Nagoya University, Nagoya, Aichi, Japan \\ ${ }^{2}$ Dept. of Atmospheric Sciences, Cochin University of Science and Technology, Kochi, Kerala, India \\ Email: madhuv68@gmail.com
}

How to cite this paper: Madhu, V. and Sudo, K. (2019) Quasi-Biennial Oscillations in Atmospheric Ozone from the Chemistry-Climate Model and Ozone Reanalysis. American Journal of Climate Change, 8, 110-136.

https://doi.org/10.4236/ajcc.2019.81007

Received: October 27, 2018

Accepted: March 2, 2019

Published: March 5, 2019

Copyright $\odot 2019$ by author(s) and Scientific Research Publishing Inc. This work is licensed under the Creative Commons Attribution International License (CC BY 4.0).

http://creativecommons.org/licenses/by/4.0/

\begin{abstract}
The quasi-biennial oscillation is the primary mode of variability of the equatorial mean zonal wind in the lower stratosphere, which is characterized by downward propagating easterly and westerly wind regimes from $10 \mathrm{hPa}$ level with a period approximately 28 months. The effects of the stratospheric quasi-biennial oscillation in zonal winds (SQBO) are not only confined to atmospheric dynamics but also seen in the chemical constituent (trace gases) anomalies such as ozone, water vapor, carbon monoxide and methane in the lower stratosphere. In this study, we examined the SQBO and associated ozone quasi-biennial oscillation (OQBO) using the chemistry-climate model CHASER (MIROC-ESM) simulations and ECMWF ERA-Interim ozone reanalysis for the period 2000-2015. We used lower stratospheric zonal wind from the radiosonde observations and total column ozone (TCO) from Aura Satellite (OMI Instruments) over Singapore to compare the SQBO and OQBO phases with model and reanalysis. The SQBO shows large variations in magnitude and periodicity during the period of study and the amplitude of OQBO also changes in accordance with the westerly (+ve ozone anomaly) and easterly (-ve ozone anomaly) phases of SQBO. During the Westerly phase of Ozone QBO (WQBO) corresponds to average positive total ozone anomaly of $\sim 10 \mathrm{DU}$ and in the Easterly phase of Ozone QBO (EQBO) corresponds to an average negative total ozone anomaly $\sim-10 \mathrm{DU}$ in the tropical lower stratosphere. Since the SQBO phases were explained by the vertical propagations of Mixed-Ross by Gravity (MRG) waves and Kelvin waves, the correlation of ozone volume mixing ratio with zonal and vertical velocities gives quasi-biennial signals, which indicate the OQBO mechanism more related to dynamical transport than the stratospheric photochemical variations. Since the average amplitude of OQBO phases gives $\sim+/-10 \mathrm{DU}$ from the observa-
\end{abstract}


tions during easterly and westerly phases SQBO, we need more research focused on the dynamical transport than the photochemical changes to understand the tropical ozone variability due to the ozone quasi-biennial oscillations.

\section{Keywords}

Ozone Layer, Equatorial Planetary Waves, Quasi-Biennial Oscillations

\section{Introduction}

The quasi-biennial oscillation is a regular variation of the zonal winds that blow high above the equatorial lower stratosphere. Strong zonal winds in the stratosphere travel in a tropical belt $\left(\sim 15^{\circ} \mathrm{S}\right.$ to $\left.15^{\circ} \mathrm{N}\right)$ around the planet, and every 14 months or so, these winds completely change direction (easterly/westerly). This means a complete cycle takes approximately 28 months, making it the most regular slow variation (descending wind speed regime) in the atmosphere after the cycle of the seasons [1] [2] [3] [4] [5]. The stratospheric quasi-biennial oscillations in zonal wind (hereafter, SQBO) are driven by vertically propagating atmospheric planetary waves (equatorially trapped Kelvin and Mixed Ross by Gravity Waves) that originate from the troposphere and are produced by intense weather systems due to convection and topography. These waves break in the tenuous stratosphere and provide a force to "push" wind and make it descend with time (at a rate of about $1 \mathrm{~km}$ per month). Once these high-level winds reach the tropopause, the opposite phase of the oscillation (easterly/westerly phase of QBO) descends from above. It takes roughly 14 months for each reversal to occur. The stratospheric quasi-biennial oscillation is observed at altitudes from about $100 \mathrm{hPa}(\sim 16 \mathrm{~km})$ to about $3 \mathrm{hPa}(\sim 40 \mathrm{~km})$ [5]. The maximum amplitude is observed in the middle and lower tropical stratosphere, with the easterly phase having larger amplitudes compared to the westerly phase. The westerly shear zones descend more regularly and rapidly than easterly shear zones. The amplitude of $20 \mathrm{~ms}^{-1}$ is nearly constant from 5 to $40 \mathrm{hPa}$ but decreases rapidly as the wind regimes descend below $50 \mathrm{hPa}$. The SQBO amplitude diminishes above 1 $\mathrm{hPa}\left(<5 \mathrm{~ms}^{-1}\right)$ and the amplitude of the SQBO is approximately Gaussian about the equator [6] [7]. The SQBO is a part of stratospheric general circulations and the dynamical connection with the extratropical stratosphere must be looked with seasonal cycles. In the tropics, the convection and changes in convection affect the tropospheric vertically propagating planetary waves, which intern impact on the SQBO [8] [9]. The tropical stratosphere circulations are influenced by the Brewer Dobson Circulations (BDC), a diabatic circulation with ascending limb in the tropical stratosphere and descending limb in the higher latitudes greatly modified by the vertically propagating equatorial planetary waves, which provides the easterly and westerly momentum to the SQBO. 
Even though the SQBO occurs in the tropical lower stratosphere, it impacts on the tropical and middle latitude atmospheric compositions and weather systems. The SQBO circulation affects the modulation of temperatures, extratropical waves, the circulation in the meridional plane and the distribution and transport of trace constituents. There have been numerous observational studies of the quasi-biennial oscillations in temperature, ozone and other trace constituents in the stratosphere [10]-[15]. Some of these studies have generally reported that the SQBO influence on total ozone amounts with positive and negative anomalies with variations of $1 \%-2 \%$. Studies suggest that the possibility of forecasting the equatorial total ozone based on the predicted SQBO phases [16]. The OQBO can be attributed to the SQBO through the variation of vertical motions of the equatorially trapped planetary waves and vertical ozone transport [17]. The first simulation of ozone QBO was done using simplified linearized model, however, it was not a full photochemical model [18]. The modelling studies of QBO variation in a one dimensional, two dimensional and three-dimensional simulations including wave driven transport are carried out by several researchers [19] [20] [21] [22] [23]. The measurement of ozone and other trace gases within the lowermost stratosphere (LMS) over Europe showed that atmospheric transport process that influence tracer distributions in the lowermost stratosphere [24]. Analyses of satellite observations by the Total Ozone Mapping Spectrometer (TOMS) revealed the influences of SQBO on the total column ozone in a global scale [25] [26] [27]. A clear quasi-biennial signature in ozone at 15 - $55 \mathrm{~km}$ was obtained by lidar observations [28]. In addition, the vertical fine structure of Ozone QBO (hereafter OQBO) variability was obtained from measurements of ozonesondes [29] and from the Southern Hemisphere Additional Ozonesondes (SHADOZ) network [30] [31]). Among various factors, the SQBO have been reported to have a significant impact on the interannual variations of the tropical ozone [32] [33]. Previous studies show that QBO-ENSO phase coupling have been major contributors to variations in stratospheric ozone [34]. Several studies are established the link of ENSO events and the coherent anomalies in zonal mean ozone in the tropical mid-lower stratosphere [35] [36] [37] [38]. Therefore, the vertical profile of the ozone concentration is linked with the QBO-ENSO phase coupling. In the tropical latitudes the quasi-biennial oscillation in total ozone, which is dynamically coupled with the equatorial zonal wind and temperature QBO in the lower stratosphere, has been reported by several authors using the ground-based observations [12] [39] and the zonal mean ozone from the satellite observations [27]. Many studies are available for the interannual variability of ozone and long-term trend, and some of these studies attributes interannual variability of tropical ozone due to stratospheric quasi-biennial oscillations [12] [29] [40]-[45]. Some of the previous results attribute the stratospheric ozone variability due to SQBO mode $17.74 \%$ and QBO-ENSO combined mode $10.41 \%$ to the total variance of the ozone [46].

The stratospheric quasi-biennial oscillation in zonal wind linked to a variety 
of atmospheric phenomenon's and the tropical weather oscillations. The pressure and circulation anomalies of the East phase of SQBO (hereafter, EQBO) are favourable for initiating El Nino events whereas anomalous conditions associated with the West phase of SQBO (WQBO) promote the "La Nina" or cold ENSO mode [47]. Studies revealed that when the El Nino and EQBO resulting low rate of seasonal hurricane activity in the Atlantic Ocean [19]. The tropical cyclone tracks in the Western North Pacific approach the East China Sea during WQBO and the eastern offshore of Japan during EQBO due to modifications of extratropical circulation by the SQBO [48]. The dependence of cyclones in the Bay of Bengal on the SQBO, found that the frequency of occurrence more during EQBO conditions and change their tracks depending on the SQBO and monsoon phases [49]. Studies also tell us that the tropospheric subtropical jet is weakened during EQBO compared to $\mathrm{WQBO}$ conditions over the north pacific region [50] [51]. The spring rain band over eastern China and the Japanese Islands is located farther south during WQBO than during EQBO conditions [52]. The Indian summer monsoon rainfall, the decay of aerosol loading following volcanic eruptions, are influenced significantly by the phases of the SQBO [53] [54] [55] [56] [57]. The statistically significant solar influence on atmosphere features was found when grouping the experimental data in accordance with the QBO phases [58] [59]. The QBO oscillations modify the strength of polar vortex and associated weather phenomenon [60]. For example, when the QBO is easterly phase (EQBO), the chances of weak jet stream, sudden stratospheric warming events and colder winters in the Northern Europe is increased and during QBO westerly phase, (WQBO) chances of a strong jet, a mild winter, winter storms and heavy rainfall increases. The major winter stratospheric warmings preferentially occur during the EQBO phase [1]. Previous studies reveal that during EQBO modulation of temperature and vertical wind shear along the tropical tropopause results in strong tropical deep convection and Hadley circulation compared to WQBO conditions [47] [61] [62] [63].

In the present study focussed on the Ozone QBO (OQBO) using the chemistry-climate model, CHASER-(MIROC-ESM) and ECMWF ERA-Interim ozone reanalysis for the period 2000-2015. We compared OQBO simulated by the model and ECMWF reanalysis from the ozone anomalies for the above period. The tropical total ozone shows positive anomaly during WQBO and negative anomaly during EQBO phases of SQBO with an approximate average variation of $+/-10 \mathrm{DU}$ can be attributed to the dynamical transport of ozone than the photochemical changes during the SQBO phases.

The manuscript is organised in such a way that, the introductory part gives a brief idea about SQBO and its impact on tracer distributions and link with regional weather changes, Section 2 describes model details and ECMWF ERA-Interim Ozone reanalysis, Section 3, describes the results and discussion on $\mathrm{SQBO}$ and $\mathrm{OQBO}$ characteristics from the model simulations, reanalysis and observations and Section 4, summary and conclusions. 


\section{Data and Methodology}

In the present analysis monthly average of daily ozone, temperature, zonal wind and vertical wind from the chemistry-climate model CHASER (MIROC-ESM) simulations and ECMWF ERA-Interim reanalysis for the period 2000-2015 were used. To study the observational verification of SQBO and OQBO phases, zonal wind at $20 \mathrm{hPa}$ from the radiosonde observations and Aura OMI satellite overpass total column ozone observations over Singapore were considered along with model simulations and reanalysis. The monthly average of ozone and other dynamical parameters were calculated from the daily six hourly (0000, 0006, 0012, 0018) model simulations and reanalysis. From the monthly parameters, we calculated the monthly zonal mean, zonal mean climatology and monthly zonal mean anomalies of ozone and other dynamical parameters to study SQBO modulated OQBO.

\subsection{Model Details}

We used the simulations of daily ozone, zonal wind, temperature and vertical velocity fields from the three-dimensional global CHemical AGCM for Studies of atmospheric Environment and Radiative forcing, CHASER-(MIROC-ESM), an atmospheric global chemistry-climate model [64] [65]. We used a model horizontal resolution of T42 (about $2.8^{\circ} \times 2.8^{\circ}$ ) with 36 vertical layers in pressure levels from the surface $(1000 \mathrm{hPa})$ to $0.5 \mathrm{hPa}$ (model top) for the present simulations for the period 2000 to 2015 . The chemical and aerosol simulations in CHASER is fully coupled with the meteorological fields in AGCM which were in this study nudged toward the National Centres for Environmental Prediction (NCEP) reanalysis data (ds083.2)/at every time step to reproduce past meteorological fields.

The AGCM generally reproduces the climatology of meteorological fields. Inclimatological simulations, CHASER uses climatological data of sea surface temperature (for the present simulation, HadiSST,

https://www.metoffice.gov.uk/hadobs/hadisst/) as an input to the AGCM. In CHASER, dynamical processes such as tracer transport, vertical diffusion, surface emissions, and deposition are simulated in the flow of the MIROC AGCM calculation. The chemistry component of CHASER calculates chemical transformations using variables of the AGCM (e.g., temperature, pressure, humidity). In the radiation component, radiative transfer and photolysis rates are calculated by using the distributions of chemical species including aerosols calculated in the chemistry component. The CHASER model simulates details of photochemistry in the troposphere and the stratosphere, chemical tracer transport, wet and dry deposition, and emissions. The model incorporates 93 species and 263 reactions (58 photolytic, 184 kinetic, and 21 heterogeneous reactions), including the chemical cycle of $\mathrm{O} x-\mathrm{NO} x-\mathrm{HO} x-\mathrm{CH} 4-\mathrm{CO}$ with volatile organic carbons (VOCs) oxidation and halogen $(\mathrm{Cl}$ and $\mathrm{Br}$ ) chemistry. The emission settings we used the EDGAR-HTAP inventory for the year 2008 for specifying anthropogenic emis- 
sion of $\mathrm{CO}, \mathrm{NOX}, \mathrm{VOCs}, \mathrm{SO}_{2}, \mathrm{BC} / \mathrm{OC}$, and $\mathrm{NH}$. All chemical reactions are calculated in the troposphere and the stratosphere.

\subsection{ECMWF ERA-Interim Reanalysis}

The European Centre for Medium-Range Weather Forecasts (ECMWF) has consistently devoted to producing consistent global reanalyses of the state of the atmosphere, land and ocean. The ERA-Interim is ECMWF's latest atmospheric reanalysis, based on a 2006 version of the Integrated Forecast Model. Interim atmospheric model and reanalysis system uses cycle 31r2 of ECMWF's Integrated Forecast System (IFS), which was introduced operationally in September 2006, configured for the following spatial resolution with 60 levels in the vertical (model top at $0.1 \mathrm{hPa}$ ), T255 spherical-harmonic representation for the basic dynamical fields and a reduced Gaussian grid with approximately uniform 79 $\mathrm{km}$ spacing for surface $\left(0.75^{\circ} \times 0.75^{\circ}\right)$ and other grid-point fields. These global fields, generated with stable and invariant versions of the ECMWF data assimilation system (DAS), have been used in many studies. ERA-Interim data assimilation system was upgraded to a four-dimensional variational data assimilation scheme (4D-Var), as opposed to the 3D-Var scheme used in ERA-40 and it made use of a variational bias correction scheme (VarBC) for satellite radiances, that automatically detects and corrects for observation biases [66] [67] [68]. The ERA-Interim produces Ozone fields in both three-dimensional fields and integrated columns from 1979 and extends to forward in time. A general detail of the ECMWF ozone system based on the ERA-40 reanalysis project are available and most of the details are still applies to the latest ECMWF reanalysis for the ozone fields [69]. The ERA-Interim project made use of a larger dataset of remotely sensed observations, both in the form of radiances and of ozone retrievals. Regarding the ozone data actively assimilated in ERA-Interim, this dataset included both data from instruments already utilized in ERA-40 and new datasets that were not used before, such as the GOME ozone profiles retrieved at the Rutherford Appleton Laboratory and NOAA-14 SBUV partial columns.

The ozone first guess used at ECMWF is derived from an updated version of the Cariolle and Déquéscheme. In this scheme the ozone continuity equation is expressed as a linear relaxation towards a photochemical equilibrium for the local value of the ozone mixing ratio, the temperature, and the overhead ozone column [70]. An additional ozone destruction term is used to parametrize the heterogeneous chemistry as a function of the equivalent chlorine content for the actual year [69], [71]. The comparisons with OMI data for the most recent years of the ERA-Interim production show a good level of agreement. Interim total column ozone (TCO) is typically within \pm 5 DU (about $\pm 3 \%$ ) from the TCO reference, while showing up to $2 \%$ lower values than the Ozone Monitoring Instrument TCO between $50^{\circ} \mathrm{S}$ and $50^{\circ} \mathrm{N}$ [72]. The only comprehensively validated reanalysis ozone fields are those from the European Centre for Medium-Range Weather Forecasts (ECMWF) reanalyses ERA-Interim [73] [74]. Therefore 
ERA-Interim ozone data are suitable for diagnosing spatial and temporal ozone variability and climate interaction studies.

\subsection{Observational Zonal Wind and Total Column Ozone}

Almost 50 years ago, the Quasi-Biennial Oscillation (QBO) of the winds in the equatorial stratosphere was detected due to the establishment of a global, regularly measuring radiosonde network [2] [75]. For the observational study of stratospheric $\mathrm{QBO}(\mathrm{SQBO})$ and Ozone $\mathrm{QBO}(\mathrm{OQBO})$, Radiosonde zonal wind at $20 \mathrm{hPa}$ and total column ozone from the Ozone Monitoring Instrument (OMI) from the Aurasatellite over Singapore, the equatorial stations were used in the present study (2005-2015). The radiosonde measurement of zonal wind and OMI Aura satellite total column ozone over Singapore can be retrieved from the following websites.

(http://www.geo.fu-berlin.de/en/met/ag/strat/produkte/qbo/index.html), zonal wind and ozone

(http://www.temis.nl/protocols/o3field/data/omi/overpass/Singapore_tm3dam_ omi.dat).

\section{Results and Discussions}

We examined quasi-biennial signals in ozone, temperature and wind from the chemistry-climate model CHASER (MIROC-ESM) and ECMWF ERA-Interim Ozone Reanalysis. Monthly zonal mean ozone and other meteorological parameters such as wind and temperature were also used in this study. The monthly averages of above parameters are calculated from the six-hourly (0000, 0006, 0012, 0018) intervals of daily data from the model simulations and reanalyses. In this study, we examined the QBO signals in ozone (positive and negative anomalies) are due to the vertical transport of ozone molecules in the stratified stratospheric ozone layer during the passage of SQBO phases. To confirm the results, we need further research to quantify the ozone variability due to SQBO dynamical cycles separately from the seasonal stratospheric photochemical ozone production and destructions.

\subsection{Zonal Mean Stratospheric Wind and Ozone Climatology}

Figure 1 represent the zonal mean climatology (monthly composite for the period 2000 to 2015$)$ of zonal wind $(\mathrm{m} / \mathrm{s})$, vertical velocity $(\mathrm{Pa} / \mathrm{s})$ and ozone volume mixing ratio (ppm) from the chemistry-climate model (hereafter, CHASER) and ECMWF-ERA Interim reanalysis (hereafter ERA-Interim) respectively at $5^{\circ} \mathrm{N}$ for the pressure levels $40 \mathrm{hPa}$ to $20 \mathrm{hPa}$. From the seasonal climatology of lower stratospheric zonal wind, there exist a winter westerly and summer easterly in the lower stratospheric. The summer easterly $(>16 \mathrm{~m} / \mathrm{s})$ is stronger than the winter westerly $(>2 \mathrm{~m} / \mathrm{s})$ in the stratosphere. The winter westerly maximum observed (February-March) at the lower stratosphere and summer easterly maxim observed (June-July) at the upper stratosphere above $20 \mathrm{hPa}$ (Figure 1(a) 

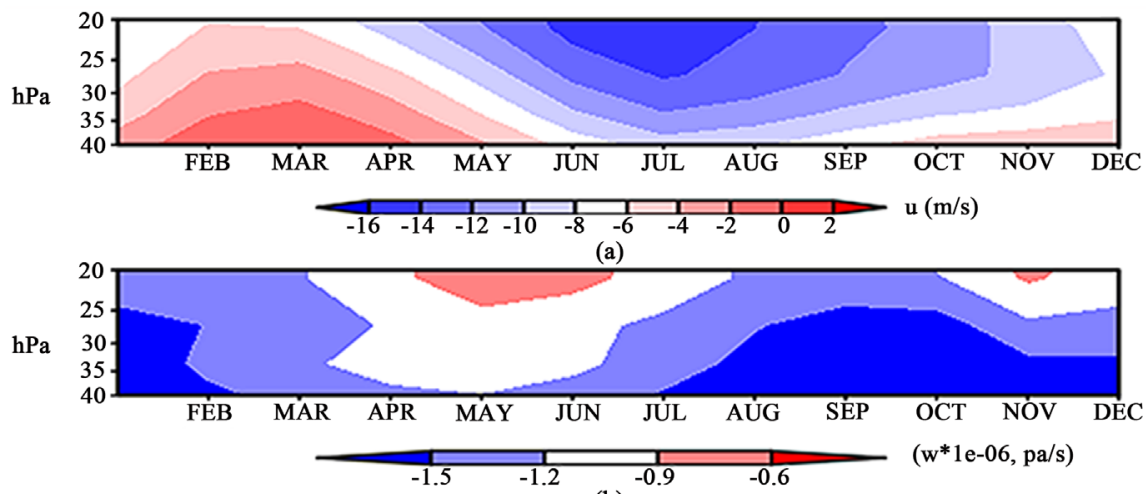

(b)

hPa
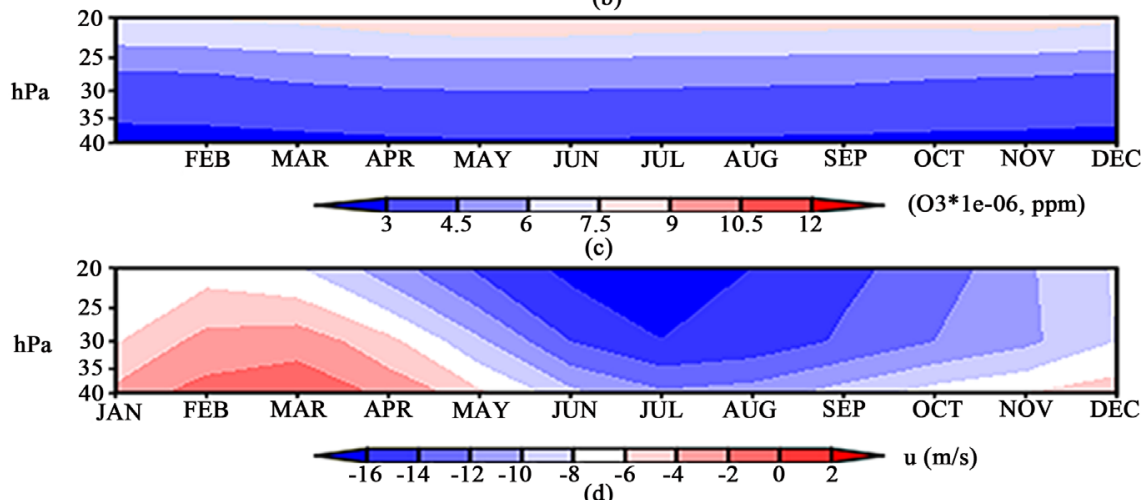

$\mathrm{hPa}$

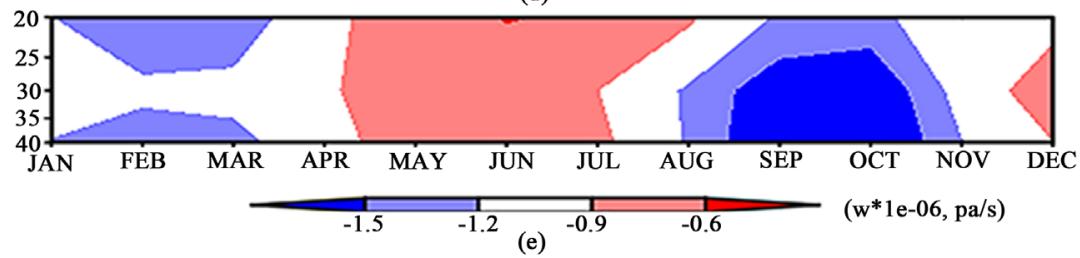

hPa

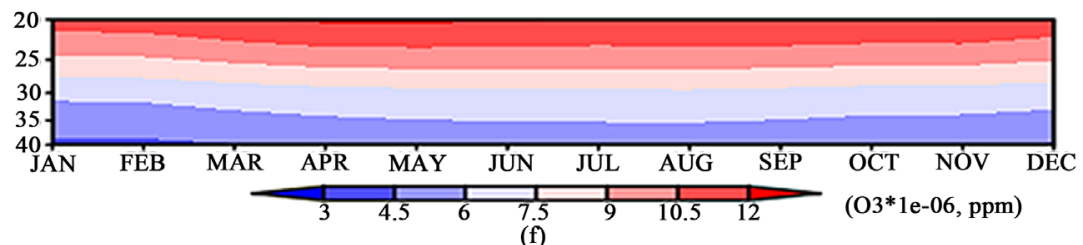

Figure 1. (a)-(f) Monthly composite of zonal means of zonal wind (m/s), vertical velocity $(\mathrm{Pa} / \mathrm{s})$ and ozone $(\mathrm{ppm})$ at $5^{\circ} \mathrm{N}$ for pressure levels $40 \mathrm{hPa}$ to $20 \mathrm{hPa}$ for the period 2000 -2015. (a)-(c) and (c)-(f) represents the zonal wind, vertical velocity and ozone mixing ratiofrom the CHASER Model and ECMWF ERA Interim reanalysis respectively during (2000-2015). (a) CHASER-Zonal mean zonal wind ( $\mathrm{u}, \mathrm{m} / \mathrm{s})$ at 5N [40 - $20 \mathrm{hPa}$; (b) CHASER-Zonal mean vertical wind- $\left(\mathrm{w}^{*} 1 \mathrm{e}-06, \mathrm{~Pa} / \mathrm{s}\right)$ at $5 \mathrm{~N}[40-20 \mathrm{hPa}]$; (c) CHASER-Zonal mean Ozone $\left(\mathrm{O}^{\star}{ }^{\star} 1 \mathrm{e}-06, \mathrm{ppm}\right)$ at $5 \mathrm{~N}$ [40 - $20 \mathrm{hPa}$; (d) ERA-Zonal mean zonal wind $(\mathrm{u}, \mathrm{m} / \mathrm{s})$ at $5 \mathrm{~N}$ [40 - $20 \mathrm{hPa}]$; (e) ERA-Zonal mean vertical wind $\left(\mathrm{w}^{\star} 1 \mathrm{e}-06\right.$, $\mathrm{Pa} / \mathrm{s})$ at $5 \mathrm{~N}$ [40 - $20 \mathrm{hPa}]$; (f) ERA-Zonal mean Ozone $\left(\mathrm{O}^{\star}{ }^{\star} 1 \mathrm{e}-06, \mathrm{ppm}\right)$ at $5 \mathrm{~N}$ [40 - 20 $\mathrm{hPa}$.

\& Figure 1(d)). The vertical velocity is negative and the magnitude is very less for all seasons in the stratosphere, since the stratified layers of the stratosphere are convectively stable compared to convective unstable troposphere. During northern summer expect the strength of the downward motion decreases $(-0.6$ $\mathrm{Pa} / \mathrm{s}$ ) from the upper to the lower stratosphere during May to July and the 
maximum downward motion $(-1.6 \mathrm{~Pa} / \mathrm{s})$ observed from September to December (Figure 1(b) \& Figure 1(e)). The zonal mean ozone layer shows a low concentration $(\sim 3 \mathrm{ppm})$ at the lower stratosphere and high concentrations ( $>12 \mathrm{ppm})$ at the upper stratosphere throughout the year above $20 \mathrm{hPa}$. The annual pattern of stratified stratospheric ozone layer concentration increases from lower to upper stratosphere (Figure 1(c) \& Figure 1(f)). The model underestimates low ozone concentration compared to the ERA-Interim reanalysis over the tropical region for the period (2000-2015). Figure 1 clearly shows the seasonal evolution of zonal mean zonal wind, vertical velocity and ozone mixing ratio. The vertically propagating planetary waves (MRG \& Kelvin waves) interact with the seasonal mean flow of zonal wind producing $\mathrm{SQBO}$, which transport ozone molecules in the stratified stratospheric ozone layer leads to quasi biennial signals in the ozone (OQBO) anomalies (Figure 1(c) \& Figure 1(f)).

\subsection{Interannual Variability of Zonal Mean Stratospheric Wind and Ozone}

Figure 2 represents the interannual variability of zonal mean zonal wind $(\mathrm{m} / \mathrm{s})$, vertical velocity $(\mathrm{Pa} / \mathrm{s})$ and ozone volume mixing ratio at $5^{\circ} \mathrm{N}$ (altitude-time plots) from the CHASER model and ERA-Interim reanalysis for pressure levels $40 \mathrm{hPa}$ to $20 \mathrm{hPa}$. The zonal wind and vertical velocity are shaded and the zero isopleth of wind velocities are marked with black contour in Figure 2. The zonal mean zonal wind clearly shows the quasi-biennial mode of westerly and easterly phases of QBO with time (Figure 2(a) \& Figure 2(d)). The interannual variability also seen in the vertical velocities with upward $(+1 \mathrm{~Pa} / \mathrm{s})$ and downward $(-4$ $\mathrm{Pa} / \mathrm{s}$ ) speed and QBO signals are very feeble in the vertical velocity (Figure 2(b) \& Figure 2(e)). The quasi-biennial periodicity is not clearly seen in the vertical velocity (upward /down ward motions) from the zonal average comparing to the zonal wind velocity. Since the magnitude of vertical velocity is very less in the atmosphere, especially at the convectively stable stratospheric layers. Figure 2(c) \& Figure 2(f) show the interannual variability of zonal mean ozone volume mixing ratio at stratospheric pressure levels from the model and ERA Interim reanalysis. The zonal mean stratospheric ozone layer undergoing interannual variability (wavy pattern in the ozone layer) with respect to time. Figures 3 (a)-(d) show the latitude-time section of the zonal mean zonal wind $(\mathrm{m} / \mathrm{s})$ and zonal mean ozone volume mixing ratio (ppm) from CHASER at $20 \mathrm{hPa}$ and ERA-Interim reanalysis at $10 \mathrm{hPa}$ levels for the tropical latitude $20^{\circ} \mathrm{S}$ to $20^{\circ} \mathrm{N}$. Figure 3(a) \& Figure 3(b) represent the zonal mean zonal wind, the easterly and westerly zonal wind is separated with zero zonal wind speed isopleths. Figure 3(c) \& Figure 3(d) display the zonal mean of ozone volume mixing ratio from the CHASER Model and ERA Interim reanalysis over the tropics. We need the ozone anomalies to display and study the OQBO phases, but SQBO can be obtained from the monthly zonal wind (easterly/westerly) measurements. 

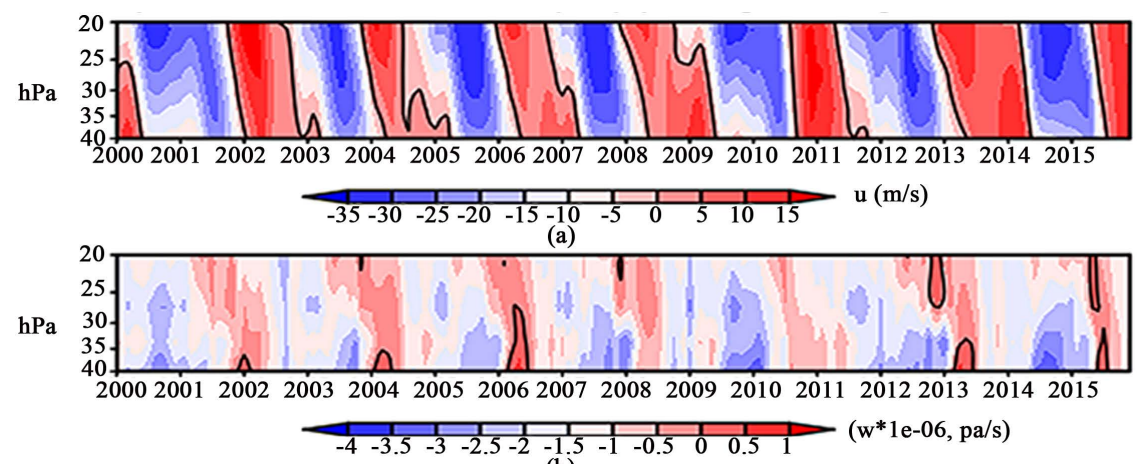

(b)

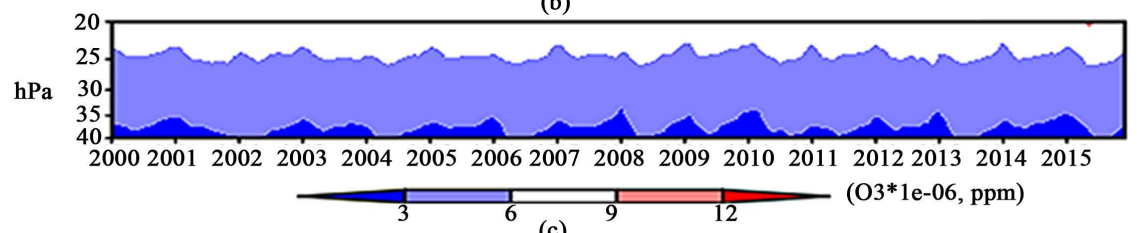

(c)

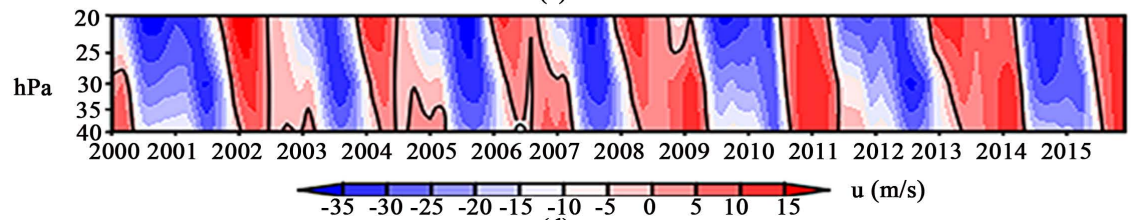

(d)

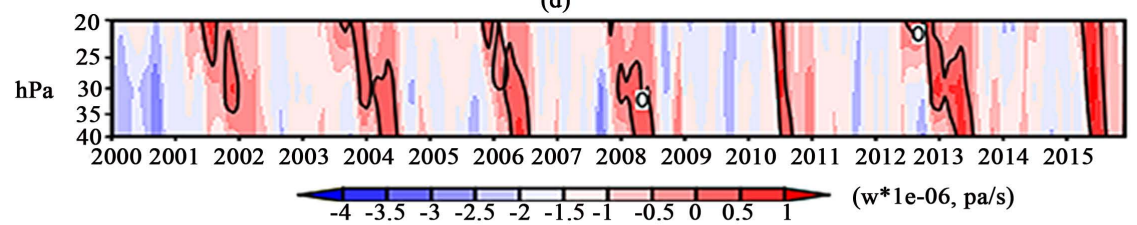

(e)

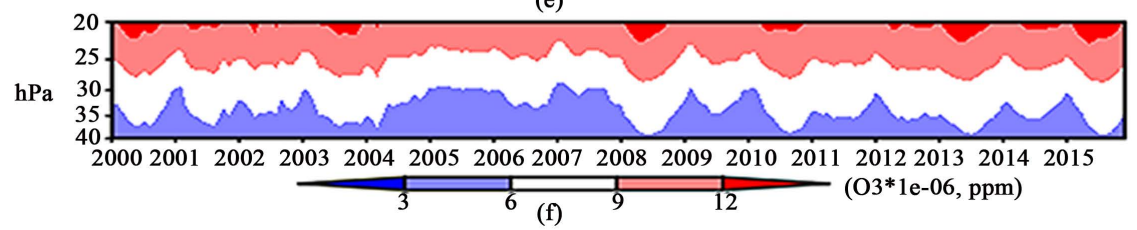

Figure 2. (a)-(f): Pressure height-time height variation zonal means of zonal wind $(\mathrm{m} / \mathrm{s})$, vertical velocity $(\mathrm{Pa} / \mathrm{s})$ and ozone $(\mathrm{ppm})$ at $5^{\circ} \mathrm{N}$ for pressure levels $40 \mathrm{hPa}$ to $20 \mathrm{hPa}$ during the period 2000-2015. Figures 1(a)-(c) and Figures 1(c)-(f) represent the zonal wind, vertical velocity and ozone mixing ration from the CHASER Model and ECMWF Reanalysis during (2000-2015). (a) CHASER-Zonal mean zonal wind (u, m/s) at $5 \mathrm{~N}[40$ $20 \mathrm{hPa}$ ]; (b) CHASER-Zonal mean vertical wind-(w*e-06, Pa/s) at 5N [40 - $20 \mathrm{hPa}]$; (c) CHASER-Zonal mean Ozone (O3*1e-06, ppm) at 5N [40 - $20 \mathrm{hPa}$ ]; (d) ERA-Zonal mean zonal wind $(\mathrm{u}, \mathrm{m} / \mathrm{s})$ at $5 \mathrm{~N}$ [ $40-20 \mathrm{hPa}]$; (e) ERA-Zonal mean vertical wind $\left(\mathrm{O}^{*} 1 \mathrm{e}-06\right.$, Ps) at $5 \mathrm{~N}[40-20 \mathrm{hPa}]$; (f) ERA-Zonal mean Ozone $\left(\mathrm{O}^{\star}{ }^{\star} 1 \mathrm{e}-06, \mathrm{ppm}\right)$ at $5 \mathrm{~N}[40-20$ hPa].

\subsection{Total Column Ozone QBO-Model and Reanalysis}

Figures 4(a)-(d), represent the total column ozone anomaly (in Dobson Units) and stratospheric zonal wind $(\mathrm{m} / \mathrm{s})$ anomaly at $20 \mathrm{hPa}$, for the best representation of SQBO over the equatorial latitude belt $\left(10^{\circ} \mathrm{S}-10^{\circ} \mathrm{N}\right)$ in the lower stratosphere using the model simulations (CHASER Model) and ERA-Interim reanalysis for the period 2000-2015. The negative total column ozone anomaly (contour interval is $-5 \mathrm{DU}$ ) and zonal wind anomalies (contour interval is $-5 \mathrm{~m} / \mathrm{s}$ ) 


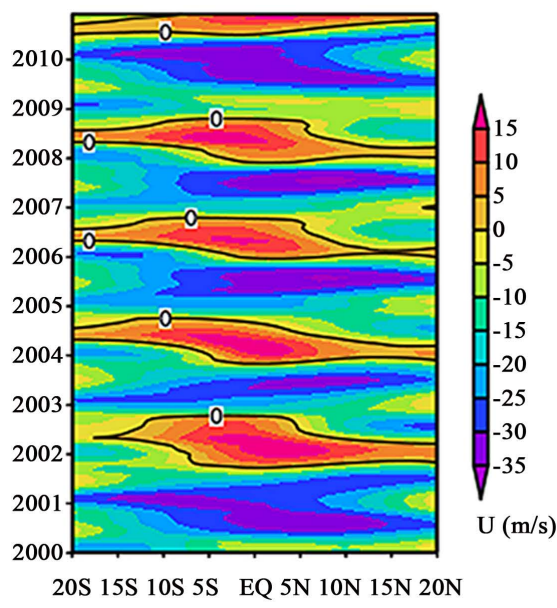

(a)

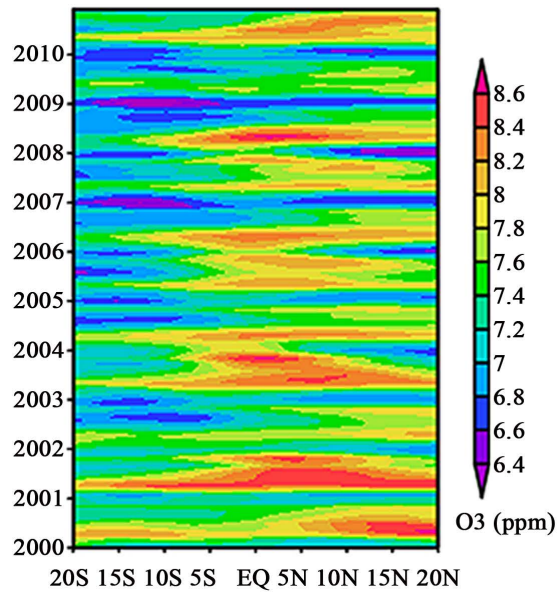

(c)

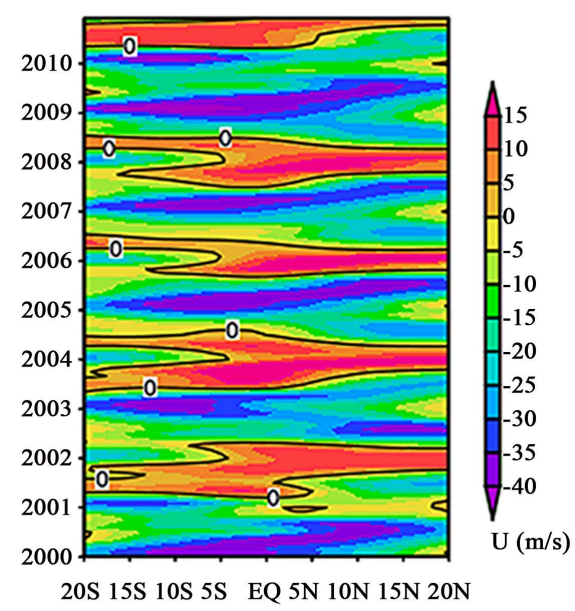

(b)

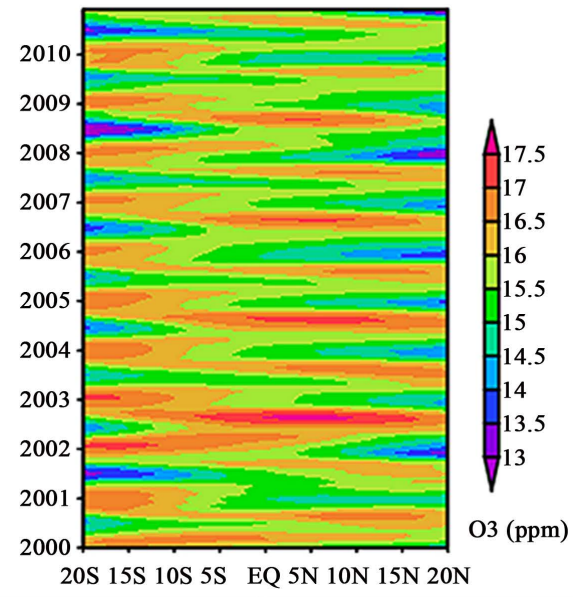

(d)

Figure 3. (a)-(d): Latitude-time variation of zonal mean zonal wind $(\mathrm{m} / \mathrm{s})$ and ozone mixing ratio (ppm) from CHASER model and ERA-Interim reanalysis. (a) \& (b) represent the zonal mean zonal wind from CHASER (at $20 \mathrm{hPa}$ ) and ERA-Interim Reanalysis (at $10 \mathrm{hPa}$ ) and ((c) \& (d)) zonal mean ozone from the CHASER (20 hPa) and ERA -Interim reanalysis $(10 \mathrm{hPa})$. (a) CHR-Zonal mean U (20 hPa); (b) ERA-Zonal mean $\mathrm{U}(10 \mathrm{hPa})$; (c) CHR-Zonal mean O3 (10 hPa); (d) ERA-Zonal mean O3 (10 hPa).

are shaded. Over the tropical stratosphere, the SQBO starts with easterly phase and end with easterly phase with total seven complete QBO cycles (7 easterly phases and 7 westerly phases) of varying amplitudes and periodicities during 2000 to 2015 (see Figure 4(b) \& Figure 4(c)). The zonal wind QBO (SQBO) and ozone $\mathrm{QBO}(\mathrm{OQBO})$ show variations in magnitude and periodicity and some point of time there is no phase coherence or lag in the OQBO with SQBO phases. During the westerly phase $(\sim+20 \mathrm{~m} / \mathrm{s}$ to $+25 \mathrm{~m} / \mathrm{s}$, WQBO) of QBO corresponds to positive ozone anomaly ( $\sim 5 \mathrm{DU}$ to $+10 \mathrm{DU}, \mathrm{WQBO})$ and in easterly phase QBO ( $-25 \mathrm{~m} / \mathrm{s}$ to $-30 \mathrm{~m} / \mathrm{s}$, EQBO) corresponds to negative ozone anomalies ( -15 DU to $-20 \mathrm{DU}, \mathrm{EQBO})$ respectively. It is interesting to note that the OQBO depends on the SQBO phases and periodicity not the magnitude (amplitude). The negative and positive anomalies of OQBO are needed to be 


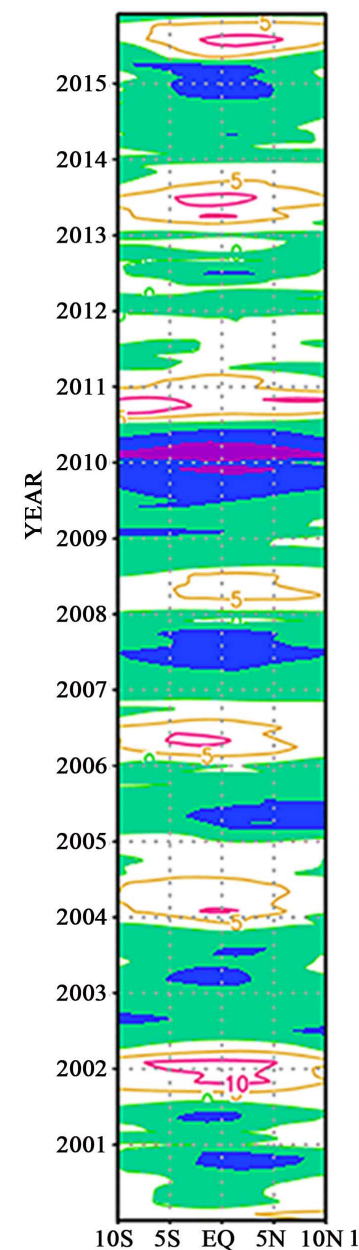

(a)

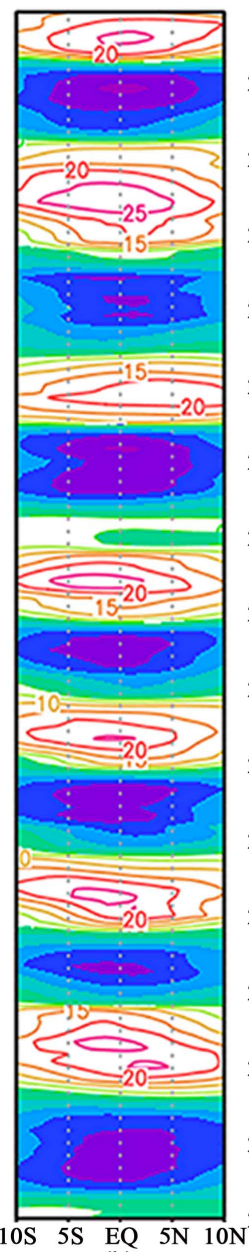

(b)

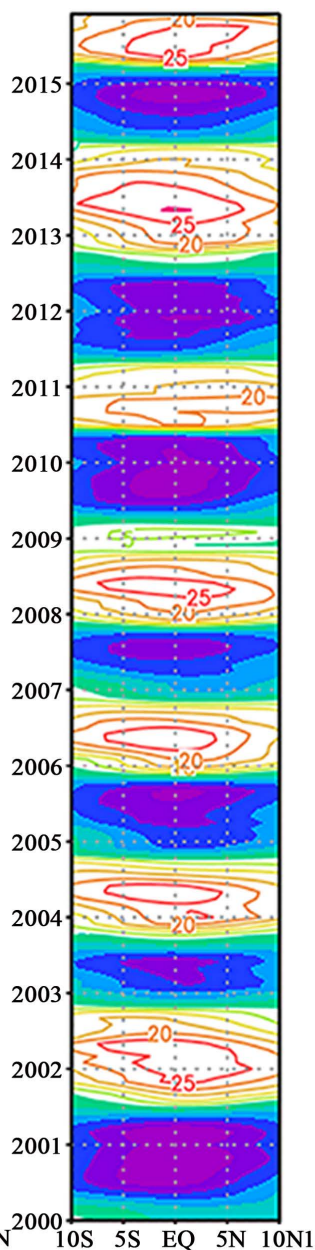

(c)

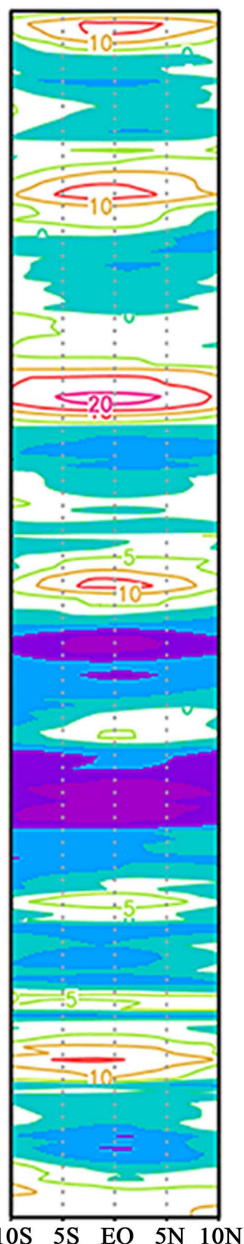

(d)

LATITUDE
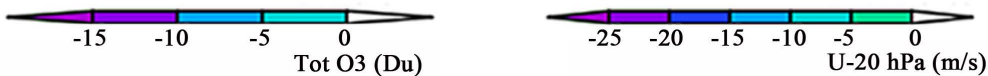

Figure 4. (a)-(d): Total Ozone QBO (in DU) and zonal wind QBO (in m/s) at $20 \mathrm{hPa}$ from the CHASER model ((a) \& (b)) and ECMWF ERA Interim Reanalysis ((c) \& (d)) respectively for the period 2000-2015. (a) CHASER-O3 (DU); (b) CHASER-U (20 hPa); (c) ERA-U (20 hPa); (d) ERA-O3 (DU).

estimated with SQBO phases to confirm the ozone concentration changes in the stratosphere. The SQBO, is a lower stratospheric phenomenon and quasi-biennial signals in total column ozone is because of total column ozone contributed from the stratosphere (90\%) compared to troposphere (10\%).

\subsection{Characteristics of SQBO and OQBO}

Figure 5 represents the longitudinal variation of zonal wind anomaly (SQBO, in $\mathrm{m} / \mathrm{s}$ ) and ozone volume mixing ratio anomaly (OQBO, in $\mathrm{ppm}$ ) at $5^{\circ} \mathrm{N}$ from CHASER and ERA-Interim reanalysis. The easterly (EQBO) and westerly (WQBO) phases of SQBO and negative and positive anomalies of OQBO are separated with a zero-isopleth black contour. Figure 5(a) \& Figure 5(b) represent the longitudinal structure of stratospheric zonal wind anomaly $(\mathrm{m} / \mathrm{s})$ from 


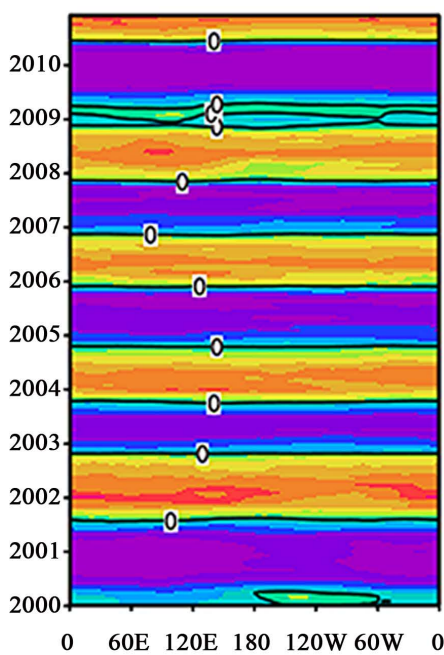

(a)

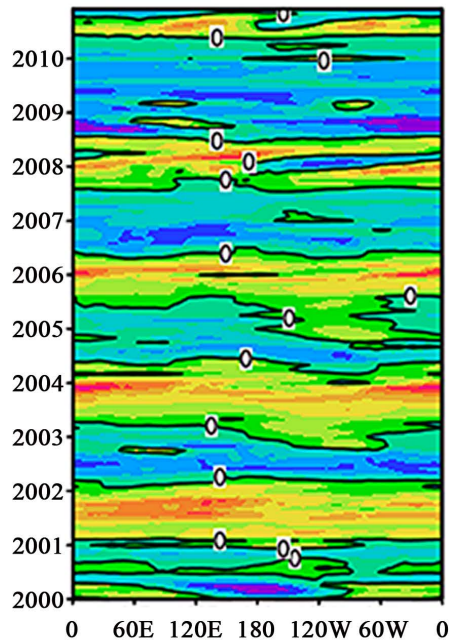

(c)

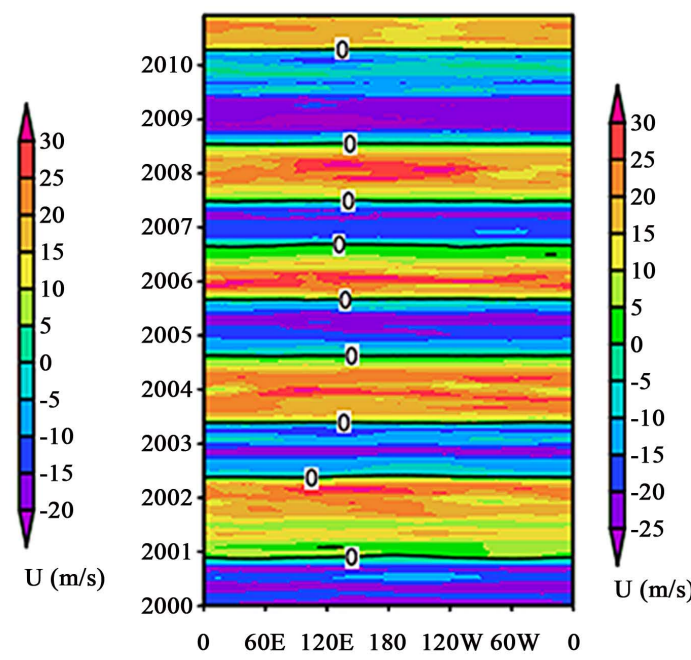

(b)

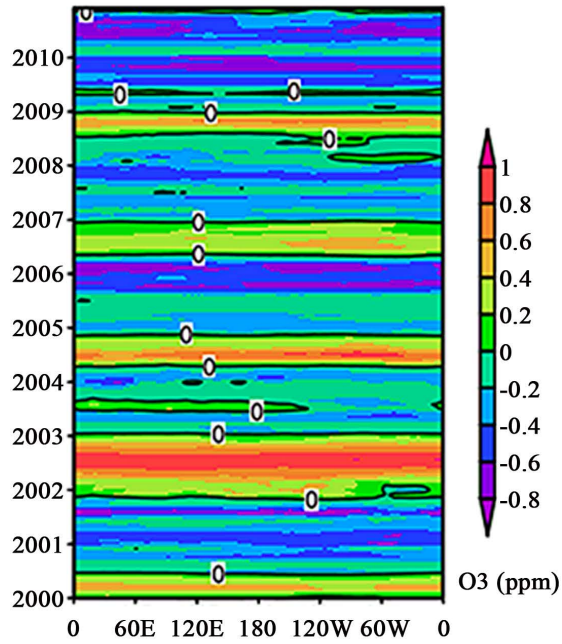

(d)

Figure 5. (a)-(d): Global zonal wind anomaly (m/s) from CHASER at $20 \mathrm{hPa}$ and ERA-Interim Reanalysis at $10 \mathrm{hPa}$ level ((a) \& (b)) and ((c) \& (d)) represent the ozone anomaly (ppm) at $10 \mathrm{hPa}$ from CHASER and ERA-Interim Reanalysis at $5 \mathrm{~N}$ for the period 2000-2010. (a) CHR-SQBO-U (5N, $20 \mathrm{hPa}$ ); (b) ERA-SQBO-U (5N, $10 \mathrm{hPa}$ ); (c) CHR-OQBO-O3 (5N, $10 \mathrm{hPa}$ ); (d) ERA-OQBO-O3 (5N, $10 \mathrm{hPa}$ ).

the CHASER model (Figure 5(a), at $20 \mathrm{hPa}$ ) and ERA -Interim reanalysis (Figure 5(b), at $10 \mathrm{hPa}$ ) respectively representing SQBO for the period 2000 to 2010. The amplitude $(\mathrm{m} / \mathrm{s})$ and periodicity (time) of EQBO and WQBO phases of SQBO are not equal but varying with time. The SQBO from the model and reanalysis shows slight difference in its periodicity and amplitude. The amplitude and periodicity of SQBO are different for stratospheric pressure levels and also depends on the descending speed of easterly (EQBO) and westerly (WQBO) phases of SQBO. The amplitude of WQBO is $\sim 30 \mathrm{~m} / \mathrm{s}$ and EQBO is $\sim 25 \mathrm{~m} / \mathrm{s}$ for the period 2000 to 2010 . Figure 5(c) \& Figure 5(d) represent the longitudinal pattern of ozone QBO (OQBO, in ppm) from the CHASER model simulations and ERA Interim reanalysis at $5^{\circ} \mathrm{N}$ for $10 \mathrm{hPa}$ level. The longitudinal variations 
of $\mathrm{OQBO}$ are seen in the ozone volume mixing anomalies (positive/negative) during the SQBO (westerly/easterly) phases. The amplitude (positive and negative anomalies) and periodicity (time duration of negative and positive anomalies) of OQBO in the upper stratosphere $(10 \mathrm{hPa})$ over the topical Pacific Ocean show great variability. The positive and negative ozone anomaly (OQBO) distribution with time around the globe clearly indicates the dynamical transport (upward/downward) of ozone during the SQBO phases.

The OQBO periodicity is different for the Eastern and Western hemispheres. The QBO pattern is interrupted due to other mode of ocean- atmospheric coupled phenomenon such as ENSO events over the tropical Pacific Ocean located in the Western Hemisphere. The distribution of ozone over tropical pacific is varying with SQBO-ENSO coupling [76] [77]. The OQBO from the CHASER model shows greater variations in amplitude and periodicity over the tropical Pacific Ocean region (see Figure 5(c)). In certain years the aptitude of ozone QBO (positive/negative anomalies) not perfectly coinciding with the phases of $\mathrm{SQBO}$. Since SQBO is due to zonal wind variation and is a dynamical phenomenon and ozone QBO (OQBO) observed in the ozone anomaly and we need more research to quantify the ozone changes due to SQBO. The OQBO show positive/negative anomalies $(\sim 1 \mathrm{ppm})$ during the westerly/easterly phase of SQBO during the period of study (Figure 5(c) \& Figure 5(d)).

\subsection{Altitude and Latitudinal Structure of Quasi-Biennial Oscillations}

Figures $6(\mathrm{a})-(\mathrm{c})$ represent the altitude-time propagation of zonal mean zonal wind $(\mathrm{m} / \mathrm{s})$, vertical velocity $(\mathrm{Pa} / \mathrm{s})$ and ozone mixing ratio $(\mathrm{ppm})$ anomalies from $40 \mathrm{hPa}$ to $20 \mathrm{hPa}$ from the CHASER model (2000-2015). The negative and positive anomalies of zonal wind, vertical velocity and ozone mixing ratio (QBO phases) are separated with zero isoplethblack contour (in Figure 6). The altitude (in pressure levels) structure of QBO propagation in atmospheric dynamical parameter such as zonal and vertical wind speed anomalies are clearly seen from Figure 6(a) and Figure 6(b). Figure 6(b) represents the upward (positive anomaly) and downward (negative anomaly) propagation of vertical velocity with QBO of periodicity. During westerly phase (WQBO) the resultant vertical motion in the lower stratosphere is positive (positive vertical velocity) or "upward transport of ozone and in the easterly phase $(\mathrm{EQBO})$ the resultant vertical motion is downward (negative vertical velocity)" or "downward transport of ozone during SQBO". In Figure 6(c) clearly shows the QBO signals in the ozone layer, due to the resultant upward transport (positive ozone anomaly) and downward transport (negative ozone anomaly) during the westerly (WQBO) and easterly (EQBO) phases of SQBO. The variation of vertical velocity resembles with the variation of ozone volume mixing ratio (see Figure 6(b) and Figure $6(\mathrm{c})$ ). The vertical residual velocity can be used a good proxy to study the stratosphere-troposphere exchange of ozone [78]. Figure 6(d) and Figure $6(\mathrm{e})$ clearly show the latitudinal extend $\left(10^{\circ} \mathrm{S}-10^{\circ} \mathrm{N}\right)$ of $\mathrm{QBO}$ signals in the 

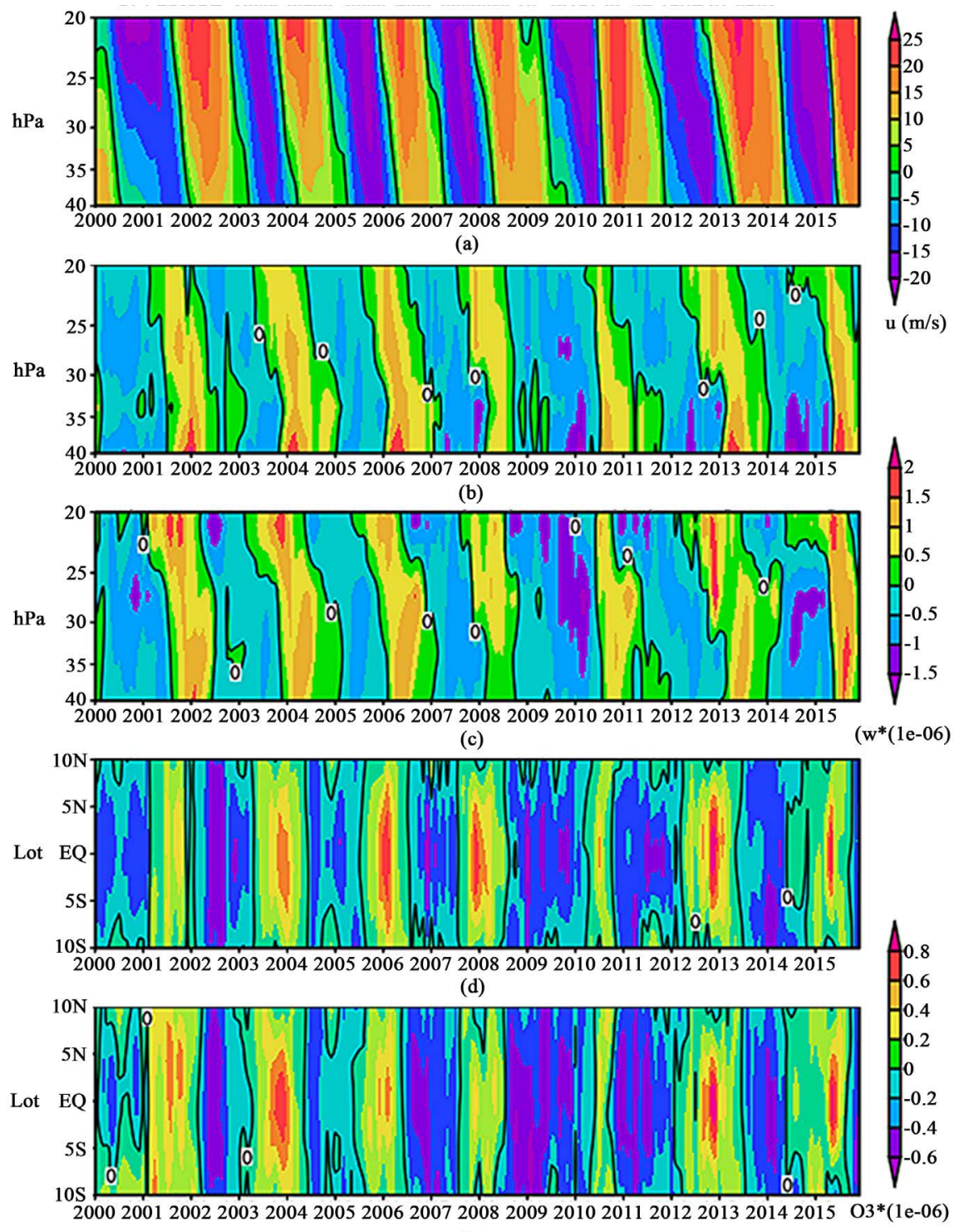

(e)

Months (2000 - 2015)

Figure 6. (a)-(e): CHASER Model (2000-2015): The vertical variation of zonal mean anomalies of (a) zonal wind $(\mathrm{m} / \mathrm{s})$; (b) vertical velocity $(\mathrm{Pa} / \mathrm{s})$ and $(\mathrm{c})$ ozone mixing ratio $(\mathrm{ppm})$ at $5^{\circ} \mathrm{N}(40-20 \mathrm{hPa})$ respectively; ((d) \& (e)) represent the latitudinal variation of $\left(10^{\circ} \mathrm{S}-10^{\circ} \mathrm{N}\right)$ of zonal mean anomalies of vertical velocity and ozone volume mixing ratio at $20 \mathrm{hPa}$. (a) CHASER-Zonal mean zonal wind anomaly (u, m/s) at 5N [40-20 hPa]; (b) CHASER-Zonal mean vertical wind anomaly- $\left(\mathrm{w}^{\star} 1 \mathrm{e}-06, \mathrm{~Pa} / \mathrm{s}\right)$ at $5 \mathrm{~N}[40-20 \mathrm{hPa}$; (c) CHASER-Zonal mean Ozone anomaly- $\left(\mathrm{O}^{\star} 1 \mathrm{e}-06, \mathrm{ppm}\right)$ at $5 \mathrm{~N}[40-20 \mathrm{hPa}]$; (d) CHASER-Zonal mean vertical wind anomaly- $\left(\mathrm{w}^{\star} 1 \mathrm{e}-06, \mathrm{~Pa} / \mathrm{s}\right)$ at $20 \mathrm{hPa}$; (e) CHASER-Zonal mean Ozone anomaly $\left(\mathrm{O}^{\star}{ }^{\star} 1 \mathrm{e}-06, \mathrm{ppm}\right)$ at $20 \mathrm{hPa}$.

anomalies of zonal mean vertical velocity and zonal mean ozone mixing ratio at $20 \mathrm{hPa}$ with a positive and negative phase correlation for the period 2000 to 2015. Figures 7(a)-(e) also represent the QBO signals in dynamical parameters such as zonal wind (SQBO), vertical velocity and in the trace constitutes such as ozone mixing ratio anomalies from the ERA-Interim Reanalysis similar to 


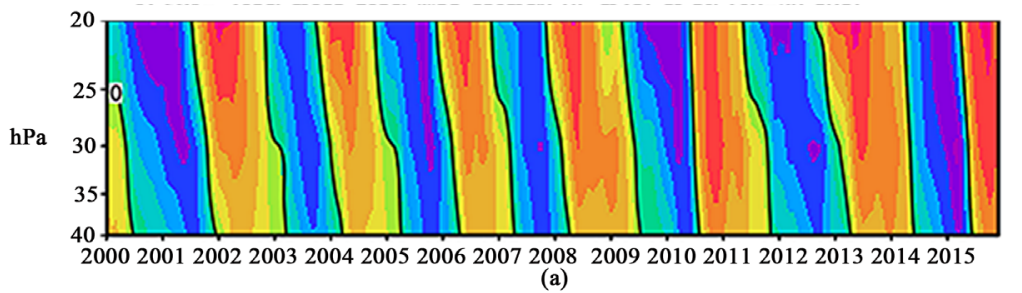

(a)

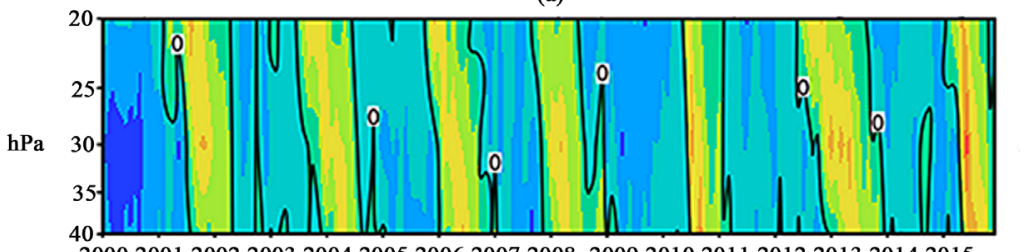

2000200120022003200420052006200720082009201020112012201320142015

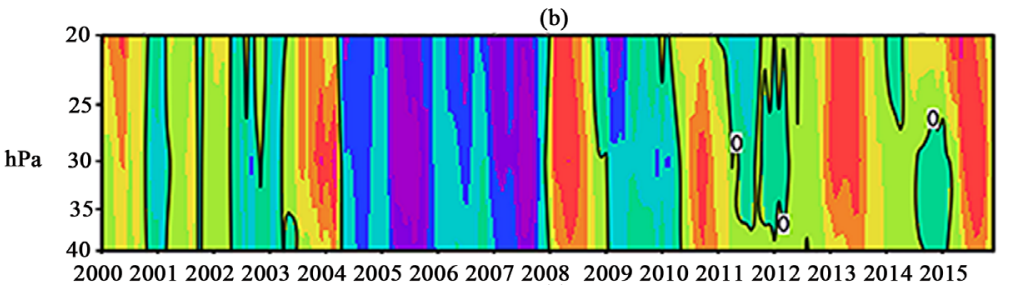

(c)

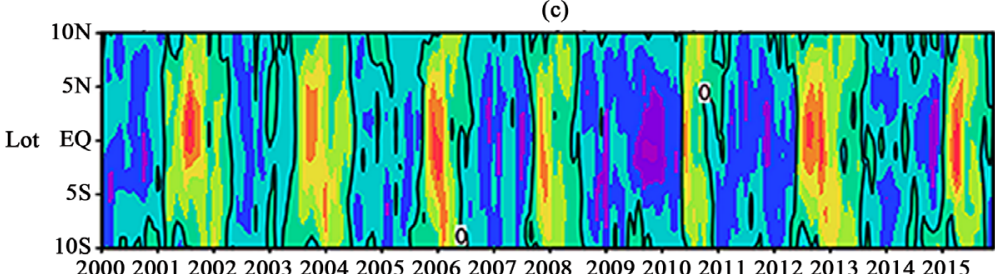

(d)
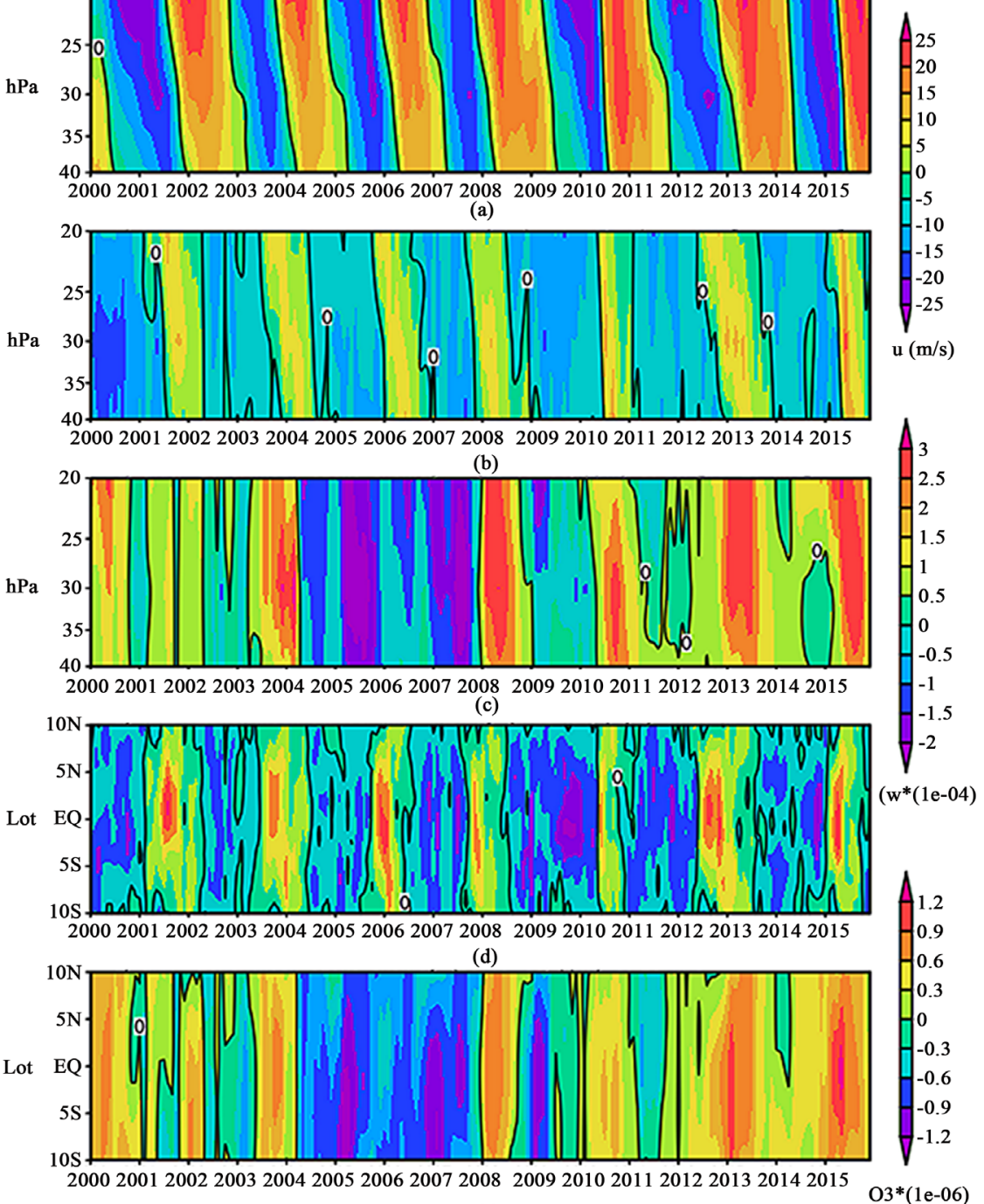

(e)

$03 *(1 e-06)$

Months (2000 - 2015)

Figure 7. (a)-(e): ERA Interim (2000-2015): The vertical variation of zonal mean anomalies of (a) zonal wind $(\mathrm{m} / \mathrm{s})$; (b) vertical velocity $(\mathrm{Pa} / \mathrm{s})$ and $(\mathrm{c})$ ozone mixing ratio $(\mathrm{ppm})$ at $5 \mathrm{~N}(40-20 \mathrm{hPa})$ respectively; ((d) \& (e)) represent the latitudinal variation of zonal mean anomalies vertical velocity and ozone volume mixing ratio at $20 \mathrm{hPa}$. (a) ERA-Zonal mean zonal wind anomaly (u, m/s) at 5N [40 - $20 \mathrm{hPa}$ ]; (b) ERA-Zonal mean vertical wind anomaly- $\left(\mathrm{w}^{\star} 1 \mathrm{e}-04, \mathrm{~Pa} / \mathrm{s}\right)$ at $5 \mathrm{~N}$ [40 - $20 \mathrm{hPa}$; (c) ERA-Zonal mean Ozone anomaly- $\left(\mathrm{O} 3^{\star} 1 \mathrm{e}-06, \mathrm{~Pa} / \mathrm{s}\right)$ at $5 \mathrm{~N}[40-20 \mathrm{hPa}]$; (d) ERA-Zonal mean vertical wind anomaly-( $\left.\mathrm{w}^{\star} 1 \mathrm{e}-04, \mathrm{~Pa} / \mathrm{s}\right)$ at $20 \mathrm{hPa}$; (e) ERA-Zonal mean Ozone anomaly (O3*1e-06, ppm) at $20 \mathrm{hPa}$.

Figure 6. It is also seen that ozone QBO (OQBO) phases are disrupted some years, for examples the negative ozone anomaly having longer periodicity in certain years (e.g. 2006 to 2008) during SQBO phase (Figure 7(c) \& Figure $7(\mathrm{e})$ ). This discrepancy in the ozone anomaly is not evident in the CHASER model and the vertical structure of OQBO phases are clearer the model simulations than the ERA-Interim Reanalysis for the level 20 to $40 \mathrm{hPa}$. 


\subsubsection{The Observational Evidence of Stratospheric Quasi-Biennial Oscillations}

Figure 8(a) and Figure 8(b), represent the zonal wind $(\mathrm{m} / \mathrm{s})$ and total column ozone anomaly (DU) from the observations, model simulations and ERA-Interim reanalysis at $20 \mathrm{hPa}$ over the tropical stations Singapore for the period 2005-2015. Figure 8(a) represents the zonal wind from the radiosonde observations, CHASER model and ECMWF ERA -Interim reanalysis over Singapore. The equatorial station Singapore $\left(1.3521^{\circ} \mathrm{N}, 103.8198^{\circ} \mathrm{E}\right)$ maintain the long-term record of stratospheric zonal wind measurements using radiosonde since 1953 to till date and this zonal wind measurement is taken as a SQBO studies (http://www.geo.fu-berlin.de/en/met/ag/strat/produkte/qbo/index.html). The easterly and westerly zonal wind shear (SQBO phases) from CHASER model and ERA-Interim reanalysis produces exact phase correlation compare with the radiosonde observations during 2005 to 2015. The magnitude of EQBO is greater $(\sim-30 \mathrm{~m} / \mathrm{s})$ than the WQBO $(\sim 20 \mathrm{~m} / \mathrm{s})$ from the model, reanalysis and observations of zonal wind over Singapore. Figure 8(b), represents the total column ozone anomalies from the Ozone Monitoring Instrument (OMI), Aura satellite, CHASER simulations and ERA-Interim reanalysis shows the QBO signals in total column ozone over Singapore for the period 2005-2015. It is noted that the

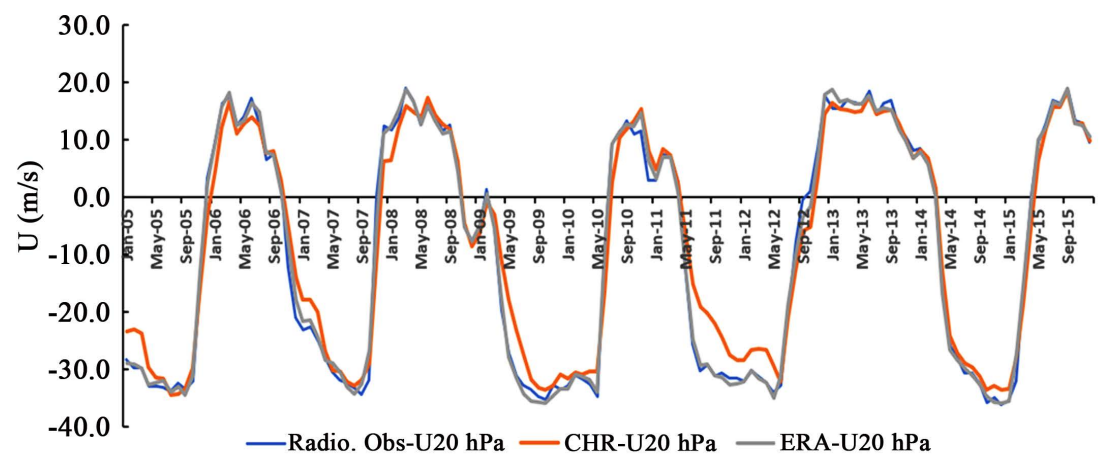

(a)

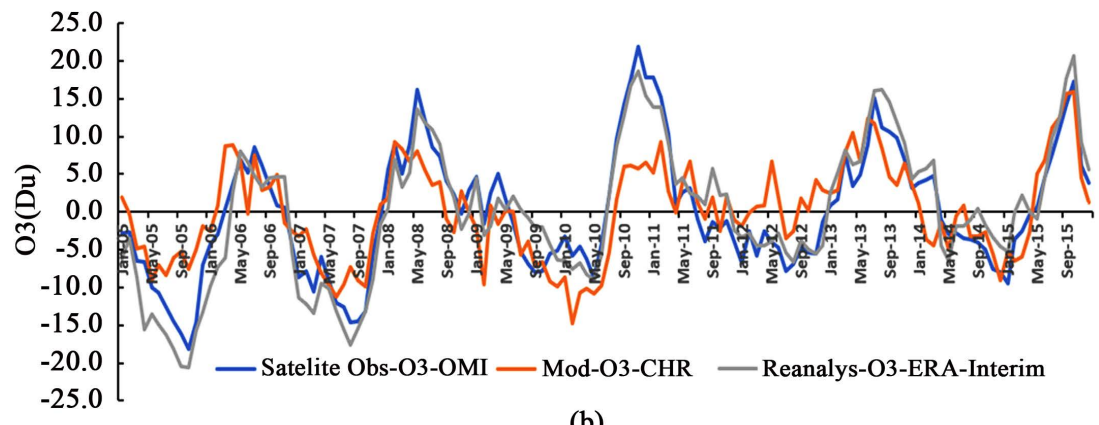

(b)

Figure 8. (a) \& (b): (a) The Quasi-Biennial Oscillations in Zonal wind (m/s) from Radiosonde measurements, chemistry climate model simulation (CHASER) and ERA-interim Reanalysis and (b) total column ozone anomaly from the OMI Aura Satellite measurements, CHASER Model simulation and ERA-Interim Reanalysis over tropical station Singapore for the period 2005-2015. (a) Singapore-Zonal wind (SQBO)-20 hPa (2005-2015); (b) Singapore-Total column ozone anomaly-(OQBO) (2005-2015). 
WQBO correspond to positive total column ozone anomaly ( $\sim+20 \mathrm{DU})$ and EQBO correspond to the negative total column ozone anomaly ( -20 DU) with a QBO periodicity. The SQBO is produced by the equatorial planetary wave dynamics and $\mathrm{OQBO}$ is based on the concentration changes (positive and negative anomalies) associated with vertical transport during the stratospheric QBO. Stratospheric $\mathrm{QBO}$ is a reality which is observed and measured in the equatorial lower stratosphere. To understand the OQBO, we need a further study to estimate the concentration changes associated dynamical transport and stratospheric ozone photochemistry during the passage of SQBO phases in the ozone layer. Since, during the SQBO phases ozone varies $\sim 20$ DU between positive and negative phases of OQBO, we need to quantify separately the stratospheric ozone changes due to the dynamical transport (SQBO phases) and photochemical changes to understand the driving mechanisms of OQBO.

\subsubsection{The Amplitude and Period of SQBO, TQBO, QBO}

Figure 9(a)-(f) represent the amplitude and period of zonal wind QBO (zonal mean zonal wind anomaly, SQBO), Temperature QBO (zonal mean temperature anomaly, TQBO) and ozone QBO (zonal mean ozone anomaly, OQBO) for the latitude $5^{\circ} \mathrm{N}$, at $30 \mathrm{hPa}$ level from CHASER model and ERA-Interim reanalysis for the period 2000-2015. The amplitude of easterly and westerly phases of SQBO oscillate between $-30 \mathrm{~m} / \mathrm{s}$ to $20 \mathrm{~m} / \mathrm{s}$ (Figure 9(a) \& Figure 9(d)), the negative and positive anomalies of $\mathrm{TQBO}$ oscillate between $-3.0^{\circ} \mathrm{C}$ to $3.0^{\circ} \mathrm{C}$ (Figure 9(d) \& Figure 9(e)) and OQBO oscillate between -1.0 and $1.0 \mathrm{ppm}$ at $5^{\circ} \mathrm{N}$ for the stratospheric pressure level at $30 \mathrm{hPa}$ for the period 2000 to 2015 (Figure 9(c) \& Figure 9(f)). Reed (1984) proposed first the mechanism to explain the quasi-biennial signals in total column ozone over the tropics and is well accepted theory of OQBO till this date [18]. This mechanism proposed that the timing of the maximum westerly vertical wind shear (WQBO) at a particular level (Figure 9(a) \& Figure 9(d)), corresponds to the warmest phase of the TQBO (positive temperature anomaly) on the equator (Figure 9(b) \& Figure $9(e)$ ). The westerly phase (WQBO) is the time for maximum diabatic cooling, which will induce relative sinking of air parcel through isentropic surface and this vertical motion occur in a region where the ozone mixing ratio increases with height and the life time of ozone changing rapidly. Below $28 \mathrm{~km}$, the life time of ozone is more and above $28 \mathrm{~km}$ the life time of ozone is less and hence the relative descend of air through this region produces increase in total column ozone, since the level above $28 \mathrm{~km}$ ozone is replaced by chemical production on relatively short timescales. Thus, column ozone occurs maximum when the air column displaced towards the lower stratosphere and occur at the time when the westerly wind regime descend to the lower stratosphere and the converse is true in the easterly phase [5], [18]. This theory is based on photochemistry of stratospheric ozone production and distributions during the westerly and easterly phases of SQBO. Hence previous studies, the positive and negative anomalies of OQBO attributed to the SQBO, such that ozone increases during the westerly 


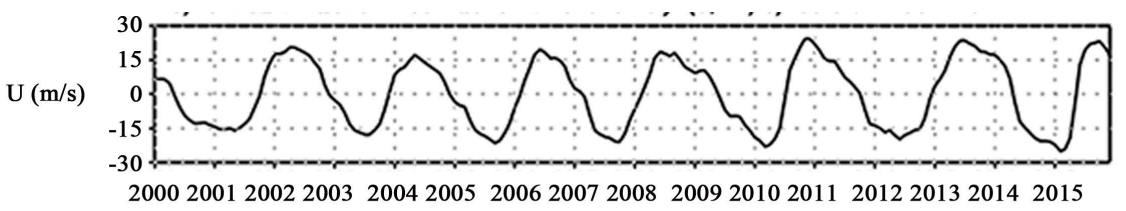

(a)

$\mathrm{T}\left({ }^{\circ} \mathrm{C}\right)$

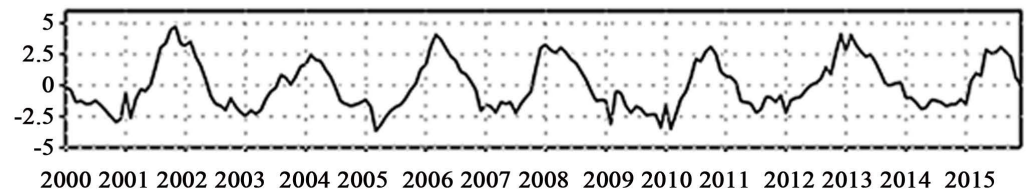

(b)

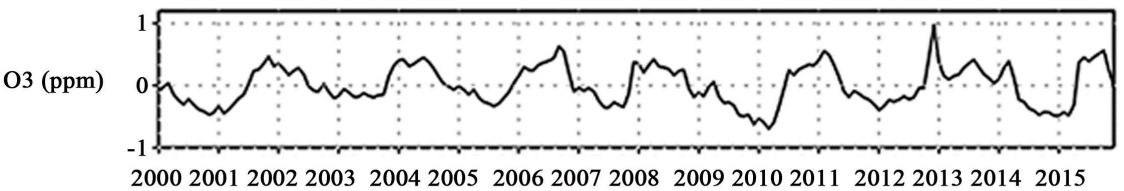

(c)

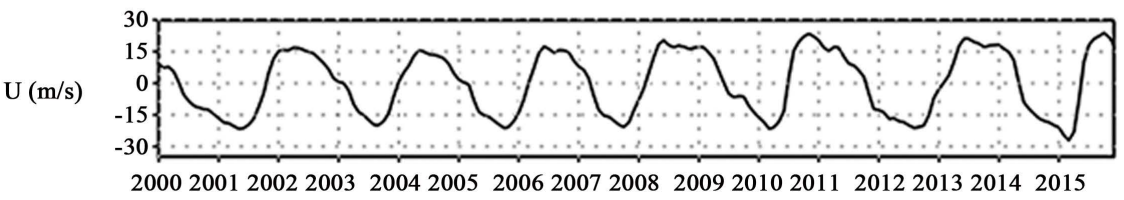

(d)

$\mathrm{T}\left({ }^{\circ} \mathrm{C}\right)$

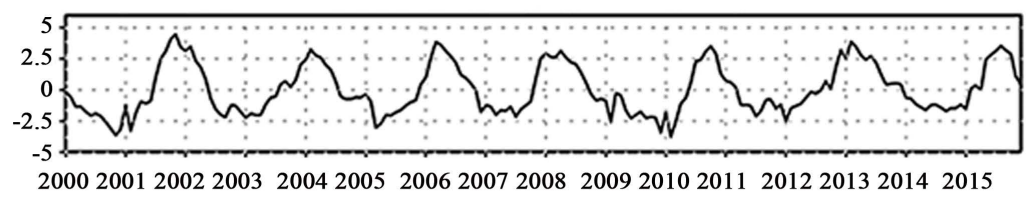

(e)

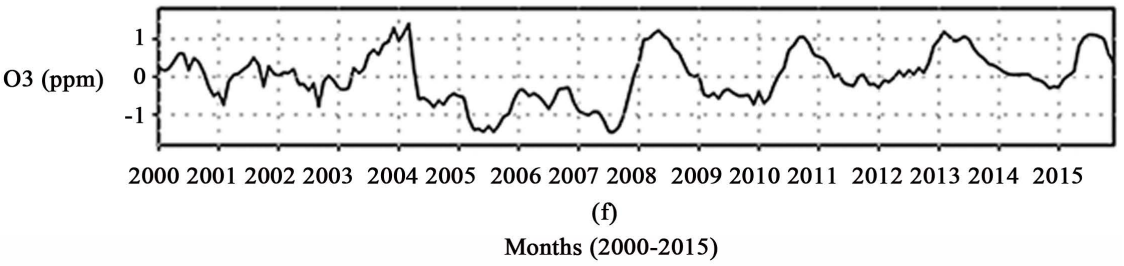

Figure 9. (a)-(f): (a)-(c) The QBO signals in zonal wind (u, m/s), temperature $\left(\mathrm{T},{ }^{\circ} \mathrm{C}\right)$ and ozone anomalies (O3, ppm) at $30 \mathrm{hPa}$ level from CHASER model and (d)-(f) from the ERA-Interim reanalysis for the period 2000 to 2015. (a) CHASER-Zonal mean zonal wind anomaly (u, m/s) at $5 \mathrm{~N}-30 \mathrm{hPa}$; (b) CHASER-Zonal mean temperature anomaly (Temp, ${ }^{\circ} \mathrm{C}$ ) at $5 \mathrm{~N}-30 \mathrm{hPa}$; (c) CHASER-Zonal mean Ozone anomaly $\left(\mathrm{O}^{\star}{ }^{\star} 1 \mathrm{e}-06, \mathrm{ppm}\right)$ at $5 \mathrm{~N}-30$ $\mathrm{hPa}$; (d) ERA-Zonal mean zonal wind anomaly (u, m/s) at $5 \mathrm{~N}-30 \mathrm{hPa}$; (e) ERA-Zonal mean temperature anomaly $\left(\mathrm{Temp},{ }^{\circ} \mathrm{C}\right)$ at $5 \mathrm{~N}-30 \mathrm{hPa}$; (f) ERA-Zonal mean Ozone anomaly $\left(\mathrm{O} 3{ }^{\star} 1 \mathrm{e}-06, \mathrm{ppm}\right)$ at $5 \mathrm{~N}-30 \mathrm{hPa}$.

(positive ozone anomaly) and decreases during the easterly phases (negative ozone anomaly) of SQBO [5], [18]. Based on this OQBO mechanism, the stratospheric ozone prediction is much easier, since we know the forecast of SQBO phases (direction changes of zonal wind) exactly [16]. 
Figures 10(a)-(d), show the spatial(grid to grid) correlation map between (a) monthly zonal wind \& vertical wind, (b) monthly zonal wind \& ozone volume mixing ratio, (c) vertical velocity \& ozone volume mixing ratio (d) temperature and ozone volume mixing ration over the tropical region $\left(1.4^{\circ} \mathrm{S}-1.4^{\circ} \mathrm{N}\right.$ Latitude \& 0 - 360 Longitude) for the pressure levels 40 to $20 \mathrm{hPa}$ from the CHASER model for the period 2000-2015 (correlation values displayed from 2003-2008 in Figure 10). The spatial correlation of zonal wind and vertical velocity shows the QBO signals indicate the SQBO mechanism based on the equatorial planetary wave (MRG \& Kelvin Waves) dynamics and interactions of vertically propagating
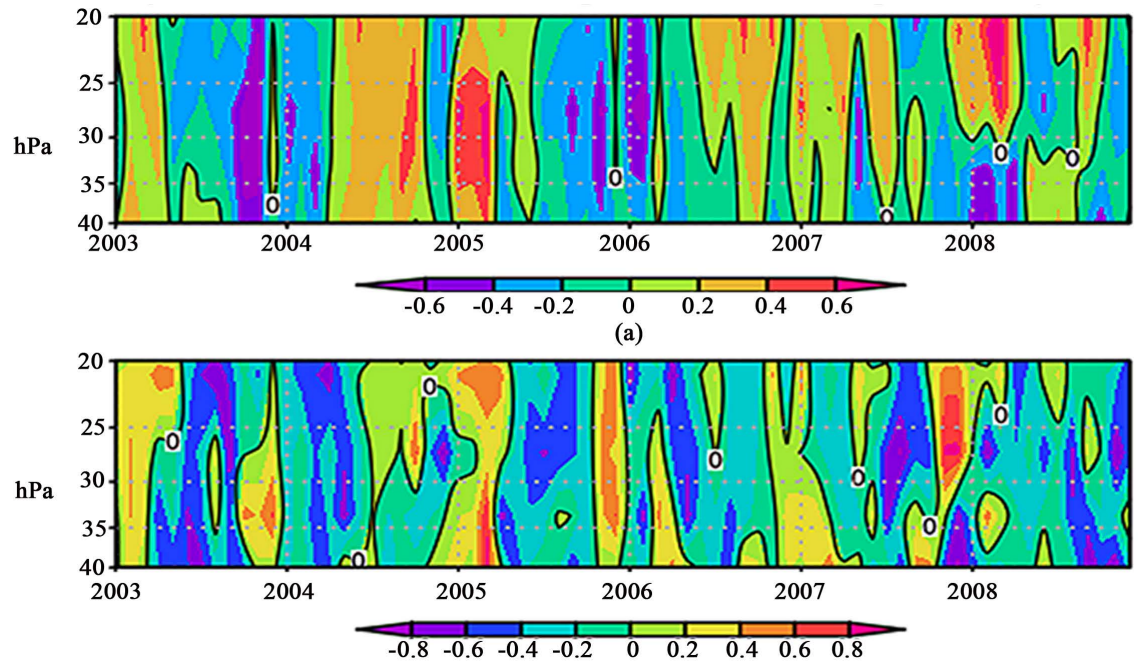

(b)

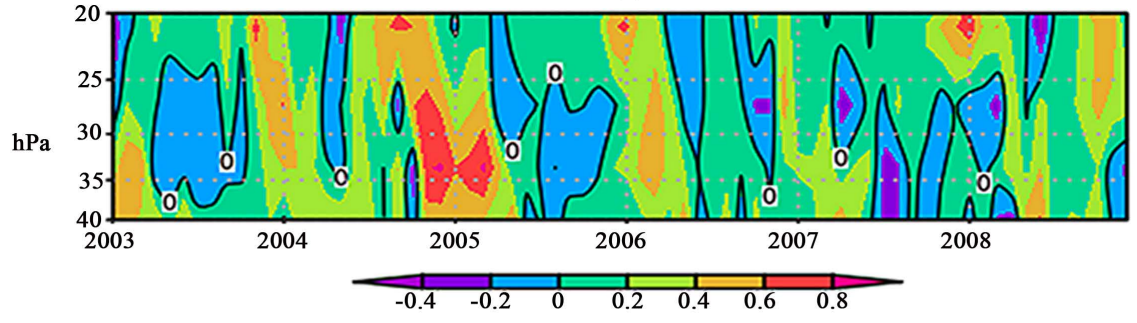

(c)

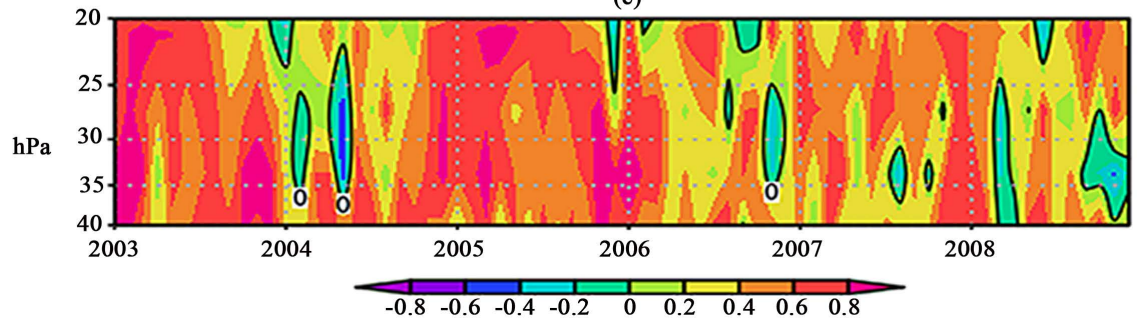

(d)

Figure 10. (a)-(d): Spatial correlation (grid to grid)of monthly (a) zonal wind \& vertical wind (b) zonal wind \& ozone mixing ratio and (c) vertical velocity \& ozone volume mixing ratio and (d) temperature \& ozone mixing ratio from the Chemistry-climate Model CHASER for the pressure levels 40 to $20 \mathrm{hPa}$ for the period 2000 to 2015 (correlation values from 2003 to 2008 shown). (a) CHASER-Correlation of U and W-[1.4S - 1.4N \& 0 - 360]-40 to $20 \mathrm{hPa}$; (b) CHASER-Correlation of U and O3-[1.4S - 1.4N \& 0 - 360]-40 to $20 \mathrm{hPa}$; (c) CHASER-Correlation of $\mathrm{W}$ and O3-[1.4S - 1.4N \& 0 - 360]-40 to $20 \mathrm{hPa}$; (d) CHASER-Correlation of $\mathrm{T}$ and O3-[1.4S - 1.4N \& $0-360]-40$ to $20 \mathrm{hPa}$. 
planetary waves (upward vertical velocity) with wind shear zones (easterly/ westerly zonal velocity) during SQBO phases (Figure 10(a)). Figure 10(b) \& Figure $10(\mathrm{c})$ show the correlation map of ozone volume mixing ratio with zonal and vertical velocities for the period 2000 to 2015 . The correlation of ozone with zonal and vertical wind velocities clearly suggest that OQBO is more linked to the dynamical transport (depend on zonal and vertical velocities) rather than the photochemical changes. The correlation of ozone volume mixing ratio and temperature do not exactly show the quasi-biennial signals indicate that Ozone QBO (positive/negative ozone anomaly) is more related to dynamical transport than stratospheric ozone photochemistry during SQBO phases (see Figure 10(d)). We need further research to evolve the OQBO mechanism based on SQBO dynamics.

\section{Summary and Conclusion}

In the present study, we examined the $\mathrm{QBO}$ signals in ozone (OQBO) using the chemistry-climate model CHASER (MIROC-ESM) and ECMWF ERA-Interim ozone Reanalysis for the period 2000-2015. The OQBO shows phase coherence with the SQBO in such way that during WQBO there is positive ozone anomaly $(\sim+10 \mathrm{DU})$ and in EQBO, a negative ozone anomaly ( -10 DU) with a quasi-biennial periodicity from the model simulation, ERA-Interim reanalysis and observations during the period of study. Reed explained OQBO mechanism (negative and positive ozone anomaly changes with time), which emphasized on the ozone concentration changes during SQBO phases [18]. The positive and negative anomalies of temperature (TQBO) and vertical velocity anomalies (upward and downward velocity) are in phase with westerly and easterly phases of stratospheric QBO. The in-phase relation of vertical velocities and SQBO reveals the vertical transport of ozone molecules in the ozone layer during the SQBO phases. The correlation patterns of ozone with vertical velocity and zonal wind show clear pattern quasi-biennial signals compared to that with temperature correlations, suggesting that $\mathrm{OQBO}$ may be more related to the dynamical transport during SQBO phases than the photochemical changes in the stratosphere. We need further research to redefine the OQBO mechanism based on SQBO mechanism, since easterly and westerly phases, the SQBO, the OQBO amplitude change almost same ( $+/-10 \mathrm{DU})$ during SQBO phases. To calculate the interannual variability and trend of tropical stratospheric ozone due to SQBO modulation, we need to estimate the percentage of variability due to the vertical transport and photochemical production and destruction of ozone separately for the SQBO phases. Hence an integrated study of SQBO phase dynamics and stratospheric ozone photochemistry is required to understand the OQBO and associated ozone variability over the tropics.

\section{Acknowledgements}

Authors are greatly thankful to the Ministry of Environment, Government of 
Japan for the financial support through the S-12, project at the Graduate School of Environmental Studies, Nagoya University, Nagoya, Japan. We also acknowledge the reviewer's suggestions and comments for the refinement of the manuscript for the better shape.

\section{Conflicts of Interest}

The authors declare no conflicts of interest regarding the publication of this paper.

\section{References}

[1] Holton, J.R. and Tan, H.C. (1980) The Influence of the Equatorial Quasi-Biennial Oscillation on the Circulation at $50 \mathrm{mb}$. Journal of the Atmospheric Sciences, 37, 2200. https://doi.org/10.1175/1520-0469(1980)037<2200:TIOTEQ >2.0.CO;2

[2] Ebdon, R.A. (1960) Notes on the Wind Flow at $50 \mathrm{mb}$ in Tropical and Subtropical Regions in January 1957 and in 1958. Quarterly Journal of the Royal Meteorological Society, 86, 540-542. https://doi.org/10.1002/qj.49708637011

[3] Ebdon, R.A. and Veryard, R.G. (1961) Fluctuations in Equatorial Stratospheric Winds. Nature, 189, 791-793. https://doi.org/10.1038/189791a0

[4] Reed, R.J., Campbell, W.J., Rasmussen, L.A. and Rogers, R.G. (1961) Evidence of a Downward Propagating Annual Wind Reversal the Equatorial Stratosphere. Journal of Geophysical Research, 66, 813-818. https://doi.org/10.1029/JZ066i003p00813

[5] Baldwin, M., Gray, L.J., Dunkerton, T.J., Hamilton, K., Haynes, P.H., Randel, W.J., et al. (2001) The Quasi-Biennial Oscillation. Reviews of Geophysics, 39, 179-229. https://doi.org/10.1029/1999RG000073

[6] Naujokat, B. (1986) An Update of the Observed Quasi-Biennial Oscillation of the Stratospheric Winds over the Tropics. Journal of the Atmospheric Sciences, 43, 1873-1877. https://doi.org/10.1175/1520-0469(1986)043<1873:AUOTOQ>2.0.CO;2

[7] Dunkerton, T.J. and Delisi, D.P. (1985) Climatology of the Equatorial Lower Stratosphere. Journal of the Atmospheric Sciences, 42, 376-396. https://doi.org/10.1175/1520-0469(1985)042<0376:COTELS>2.0.CO;2

[8] Collimore, C., Martin, D. and Hitchmann, M. (2003) On the Relationship between the QBO and Tropical Deep Convection. Journal of Climate, 16, 2552-2568. https://doi.org/10.1175/1520-0442(2003)016<2552:OTRBTQ >2.0.CO;2

[9] Schirber, S., Manzini, E. and Alexander, M.J. (2014) A Convection-Based Gravity Wave Parameterization in a General Circulation Model: Implementation and Improvements on the QBO. Journal of Advances in Modeling Earth Systems, 6, 264-279. https://doi.org/10.1002/2013MS000286

[10] Angell, J.K. and Korshover, J. (1970) Quasi-Biennial, Annual, and Semi-Annual Zonal Wind and Temperature Harmonic Amplitudes and Phases in the Stratosphere and Low Mesosphere of the Northern Hemisphere. Journal of Geophysical Research, 75, 543-550. https://doi.org/10.1029/JC075i003p00543

[11] Oltmans, S.J. and London, J. (1982) The Quasi-Biennial Oscillation in Atmospheric Ozone. Journal of Geophysical Research Oceans, 87, 8981-8989. https://doi.org/10.1029/JC087iC11p08981

[12] Hasebe, F. (1994) Quasi-Biennial Oscillations of Ozone and Diabatic Circulation in the Equatorial Stratosphere. Journal of the Atmospheric Sciences, 51, 729-745. https://doi.org/10.1175/1520-0469(1994)051<0729:QBOOOA>2.0.CO;2

[13] Zawodny, J.M. and McCormick, M.P. (1991) Stratospheric Aerosol and Gas Ex- 
periment II: Measurements of the Quasi-Biennial Oscillation in Ozone and Nitrogen Dioxide. Journal of Geophysical Research, 96, 9371-9377. https://doi.org/10.1029/91JD00517

[14] Pawson, S. and Fiorino, M. (1998) A Comparison of Reanalyses in the Tropical Stratosphere. Part 2: The Quasi-Biennial Oscillation. Climate Dynamics, 14, 645-658. https://doi.org/10.1007/s003820050247

[15] Randel, W.J. and Cobb, J.B. (1994) Coherent Variations of Monthly Mean Total Ozone and Lower Stratospheric Temperature. Journal of Geophysical Research, 99, 5433-5447. https://doi.org/10.1029/93JD03454

[16] Gabis, I.P. (2014) Quasi-Biennial Oscillation (QBO) of Tropical Total Ozone under Alternative QBO Scenarios of Equatorial Stratospheric Wind. Advances in Space Research, 54, 2499-2510. https://doi.org/10.1016/j.asr.2014.01.019

[17] Plumb, R.A. and Bell, R.C. (1982) A Model of the Quasi-Biennial Oscillation on an Equatorial Beta-Plane. Quarterly Journal of the Royal Meteorological Society, 108, 335-352. https://doi.org/10.1002/qj.49710845604

[18] Reed, R.J. (1964) A Tentative Model of the 26-Month Oscillation in Tropical Altitudes. Quarterly Journal of the Royal Meteorological Society, 90, 441-466. https://doi.org/10.1002/qj.49709038607

[19] Gray, L.J. and Pyle, J.A. (1989) A Two-Dimensional Model of the Quasi-Biennial Oscillation in Ozone. Journal of the Atmospheric Sciences, 46, 203-220. https://doi.org/10.1175/1520-0469(1989)046<0203:ATDMOT>2.0.CO;2

[20] Ling, X.-D. and London, J. (1986) The Quasi-Biennial Oscillation of Ozone in the Tropical Middle Stratosphere: A One-Dimensional Model. Journal of the Atmospheric Sciences, 43, 3122-3136. https://doi.org/10.1175/1520-0469(1986)043<3122:TQBOOO >2.0.CO;2

[21] Gray, L.J. and Chipperfield, M.P. (1990) On the Interannual Variability of Trace Gases in the Middle Atmosphere. Geophysical Research Letters, 17, 933-936. https://doi.org/10.1029/GL017i007p00933

[22] Hess, P.G. and Sullivan, D.O. (1995) A Three-Dimensional Modelling Study of the Extratropical Quasi-Biennial Oscillation in Ozone. Journal of the Atmospheric Sciences, 52, 1539-1554. https://doi.org/10.1175/1520-0469(1995)052<1539:ATDMSO >2.0.CO;2

[23] Takahashi, M. (1996) Simulation of the Stratospheric Quasi-Biennial Oscillation Signal in General Circulation Model. Geophysical Research Letters, 23, 661-664. https://doi.org/10.1029/95GL03413

[24] Hegglin, M.I., Brunner, D., Peter, T., Hoor, P., Fischer, H., Staehelin, J., Krebsbach, M., Schiller, C., Parchatka, U. and Weers, U. (2006) Measurements of NO, $\mathrm{NO}_{y}$, $\mathrm{N}_{2} \mathrm{O}$, and $\mathrm{O}_{3}$ during SPURT: Implications for Transport and Chemistry in the Lowermost Stratosphere. Atmospheric Chemistry and Physics, 6, 1331-1350. https://doi.org/10.5194/acp-6-1331-2006

[25] Bowman, K.P. (1989) Global Patterns of the Quasi-Biennial Oscillation in Total Ozone. Journal of the Atmospheric Sciences, 46, 3328-3343. https://doi.org/10.1175/1520-0469(1989)046<3328:GPOTQB >2.0.CO;2

[26] Lait, L., Schoeberl, M.R. and Newman, P.A. (1989) Quasi-Biennial Modulation of the Antarctic Ozone Depletion. Journal of Geophysical Research, D94, 11559-11571. https://doi.org/10.1029/JD094iD09p11559

[27] Madhu, V. (2014) Spatial and Temporal Variability of Total Column Ozone over the Indian Subcontinent: A Study Based on Nimbus-7 TOMS Satellite. Atmospheric and Climate Sciences, 4, 884-898. https://doi.org/10.4236/acs.2014.45078 
[28] Leblanc, T. and McDermid, I.S. (2001) Quasi-Biennial Oscillation Signatures in Ozone and Temperature Observed by Lidar at Mauna Loa, Hawaii $\left(19.5^{\circ} \mathrm{N}, 155.6\right.$ $\left.{ }^{\circ} \mathrm{W}\right)$. Journal of Geophysical Research, 106, 14,869-14,874. https://doi.org/10.1029/2001JD900162

[29] Logan, J.A., Jones, D.B.A., Megretskaia, I.A., Oltmans, S.J., Johnson, B.J., Vomel, H., Randel, W.J., Kimani, W. and Schmidli, F.J. (2003) Quasi Biennial Oscillation in Tropical Ozone as Revealed by Ozonesonde and Satellite Data. Journal of Geophysical Research, 108, 4244. https://doi.org/10.1029/2002JD002170

[30] Witte, J.C., Schoeberl, M.R., Douglass, A.R. and Thompson, A.M. (2008) The Quasi-Biennial Oscillation and Annual Variations in Tropical Ozone from SHADOZ and HALOE, Atmospheric Chemistry and Physics, 8, 3929-3936. https://doi.org/10.5194/acp-8-3929-2008

[31] Lee, S., Shelow, D.M., Thompson, A.M. and Miller, S.K. (2010) QBO and ENSO Variability in Temperature and Ozone from SHADOZ, 1998-2005. Journal of Geophysical Research, 115, D18105. https://doi.org/10.1029/2009JD013320

[32] Garcia, R.A. and Solomon, S. (1987) A Possible Relationship between Interannual Variability in Antarctic Ozone and the Quasi-Biennial Oscillations. Geophysical Research Letters, 4, 848-851. https://doi.org/10.1029/GL014i008p00848

[33] Bodeker, G.E. and Scourfield, M.W.J. (1995) Planetary Waves in Total Ozone and Their Relation to Antarctic Ozone Depletion. Geophysical Research Letters, 22, 2949-2952. https://doi.org/10.1029/95GL01778

[34] Randel, W.J. and Thompson, A.M. (2011) Interannual Variability and Trends in Tropical Ozone Derived from SAGE II Satellite Data and SHADOZ Ozonesondes. Journal of Geophysical Research, 116, D07303. https://doi.org/10.1029/2010JD015195

[35] Brönnimann, S., Schraner, M., Müller, B., Fischer, A., Brunner, D., Rozanov, E. and Egorova, T. (2006) The 1986-1989 ENSO Cycle in a Chemical Climate Model. Atmospheric Chemistry and Physics, 6, 4669-4685. https://doi.org/10.5194/acp-6-4669-2006

[36] Fischer, A., Shindell, D., Bourqui, M., Faluvegi, G., Rozanov, E., Schraner, M. and Brönnimann, S. (2008) Stratospheric Winter Climate Response to ENSO in Three Chemistry-Climate Models. Geophysical Research Letters, 35, L13819. https://doi.org/10.1029/2008GL034289

[37] Cagnazzo, C., et al. (2009) Northern Winter Stratospheric Temperature and Ozone Responses to ENSO Inferred from an Ensemble of Chemistry Climate Models. Atmospheric Chemistry and Physics, 9, 8935-8948.

https://doi.org/10.5194/acp-9-8935-2009

[38] Hood, L.L., Soukharev, B.E. and McCormack, J.P. (2010) Decadal Variability of the Tropical Stratosphere: Secondary Influence of the El Niño-Southern Oscillation. Journal of Geophysical Research, 115, D11113. https://doi.org/10.1029/2009JD012291

[39] Angell, J. and Korshover, J. (1973) Quasi-Biennial and Long-Term Fluctuations in Total Ozone. Monthly Weather Review, 101, 426-443. https://doi.org/10.1175/1520-0493(1973)101<0426:QALFIT>2.3.CO;2

[40] Ramanathan, K.R. (1963) Bi-Annual Variation of Atmospheric Ozone over the Tropics. Quarterly Journal of the Royal Meteorological Society, 89, 540-542. https://doi.org/10.1002/qj.49708938209

[41] Camp, C.D., Roulston, M.S. and Yung, Y.L. (2003) Temporal and Spatial Patterns of the Interannual Variability of Total Ozone in the Tropics. Journal of Geophysical 
Research, 108, 4643. https://doi.org/10.1029/2001JD001504

[42] Fadnavis, S., Beig, G. and Polade, S.D. (2008) Features of Ozone Quasi-Biennial Oscillation in the Vertical Structure of Tropics and Subtropics. Meteorology and Atmospheric Physics, 99, 221-231. https://doi.org/10.1007/s00703-007-0270-7

[43] Fadnavis, S. and Beig, G. (2009) Quasi-Biennial Oscillation in Ozone and Temperature over Tropics. Journal of Atmospheric and Solar-Terrestrial Physics, 71, 257-263. https://doi.org/10.1016/j.jastp.2008.11.012

[44] Nair, P.J., Godin-Beekmann, S., Kuttippurath, J., Ancellet, G., Goutail, F., Pazmiño, A., Froidevaux, L., Zawodny, J.M., Evans, R.D., Wang, H.J., Anderson, J. and Pastel, M. (2013) Ozone Trends Derived from the Total Column and Vertical Profiles at a Northern Mid-Latitude Station. Atmospheric Chemistry and Physics, 13, 10373-10384. https://doi.org/10.5194/acp-13-10373-2013

[45] Tummon, F., Hassler, B., Harris, N.R.P., Staehelin, J., Steinbrecht, W., Anderson, J., Bodeker, G.E., Bourassa, A., Davis, S.M., Degenstein, D., Frith, S.M., Froidevaux, L., Kyrölä, E., Laine, M., Long, C., Penckwitt, A.A., Sioris, C.E., Rosenlof, K.H., Roth, C., Wang, H.-J. and Wild, J. (2015) Inter-Comparison of Vertically Resolved Merged Satellite Ozone Data Sets: Interannual Variability and Long-Term Trends. Atmospheric Chemistry and Physics, 15, 3021-3043.

https://doi.org/10.5194/acp-15-3021-2015

[46] Xie, F., Li, J., Tian, W., Zhang, J. and Sun, C. (2014) The Relative Impacts of El Niño Modoki, Canonical El Niño, and QBO on Tropical Ozone Changes since the 1980s. Environmental Research Letters, 9, Article ID: 064020.

http://iopscience.iop.org/article/10.1088/1748-9326/9/6/064020/pdf https://doi.org/10.1088/1748-9326/9/6/064020

[47] Gray, W.M., Sheaffer, J.D. and Knaff, J.A. (1992) Influence of the Stratospheric QBO on ENSO Variability. Journal of the Meteorological Society of Japan, 70, 975-995. https://doi.org/10.2151/jmsj1965.70.5_975

[48] Ho, C.-H., Kim, H.-S, Jeong, J.-H. and Son, S.-W. (2009) Influence of Stratospheric Quasi-Biennial Oscillation on Tropical Cyclone Tracks in the Western North Pacific. Geophysical Research Letters, 36, L06702. https://doi.org/10.1029/2009GL037163

[49] Fadnavis, S., Chakraborty, T., Ghude, S.D., Beig, G. and Raj, P.E. (2011) Modulation of Cyclone Tracks in the Bay of Bengal by QBO. Journal of Atmospheric and Solar-Terrestrial Physics, 73, 1868-1875. https://doi.org/10.1016/j.jastp.2011.04.014

[50] Garfinkel, C.I. and Hartmann, D.L. (2011) The Influence of the Quasi-Biennial Oscillation on the Troposphere in Winter in a Hierarchy of Models. Part I: Simplified dry GCMs. Journal of the Atmospheric Sciences, 68, 1273-1289. https://doi.org/10.1175/2011JAS3665.1

[51] Garfinkel, C.I. and Hartmann, D.L. (2011) The Influence of the Quasi-Biennial Oscillation on the Troposphere in Winter in a Hierarchy of Models. Part II: Perpetual Winter WACCM Runs. Journal of the Atmospheric Sciences, 68, 2026-2041. https://doi.org/10.1175/2011JAS3702.1

[52] Seo, J., Choi, W., Youn, D., Park, D.S.R. and Kim, J.Y. (2013) Relationship between the Stratospheric Quasi-Biennial Oscillation and the Spring Rainfall in the Western North Pacific. Geophysical Research Letters, 40, 5949-5953. https://doi.org/10.1002/2013GL058266

[53] Bhalme, H.N., Rahalkar, S.S. and Sikder, A.B. (1987) Tropical Quasi-Biennial Oscillation of the 10-mb Wind and Indian Monsoon Rainfall-Implications for Forecasting. Journal of Climatology, 7, 345-353. https://doi.org/10.1002/joc.3370070403 
[54] Mukherjee, B.K., Indira, K., Reddy, R.S. and Ramana Murthy, Bh.V. (1985) Quasi-Biennial Oscillation in Stratospheric Zonal Wind and Indian Summer Monsoon. Monthly Weather Review, 111, 1421-1424. https://doi.org/10.1175/1520-0493(1985)113<1421:QBOISZ>2.0.CO;2

[55] Madhu, V. (2014) Variation of Zonal Winds in the Upper Troposphere and Lower Stratosphere in Association with Deficient and Excess Indian Summer Monsoon Scenario. Atmospheric and Climate Sciences, 4, 685-695. https://doi.org/10.4236/acs.2014.44062

[56] Thomas, M.A., Giorgetta, M.A., Timmreck, C., Graf, H.-F. and Stenchikov, G. (2008) Simulation of the Climate Impact of Mt. Pinatubo Eruption Using ECHAM5 Part 2: Sensitivity to the Phase of the QBO. Atmospheric Chemistry and Physics Discussions, 8, 9239-9261. http://www.atmos-chem-phys-discuss.net/8/9239/2008/ https://doi.org/10.5194/acpd-8-9239-2008

[57] Giorgetta, M.A., Bengtsson, L. and Arpe, K. (1999) An Investigation of QBO Signals in the East Asian and Indian Monsoon in GCM Experiments. Climate Dynamics, 15, 435-450. https://doi.org/10.1007/s003820050292

[58] Labitzke, K. (2004) On the Signal of the 11-Year Sunspot Cycle in the Stratosphere and Its Modulation by the Quasi Biennial Oscillation. Journal of Atmospheric and Solar-Terrestrial Physics, 66, 1151-1157. https://doi.org/10.1016/j.jastp.2004.05.011

[59] Labitzke, K. (2005) On the Solar Cycle QBO Relationship: A Summary. Journal of Atmospheric and Solar-Terrestrial Physics, 67, 45-54. https://doi.org/10.1016/j.jastp.2004.07.016

[60] Watson, P.A.G. and Lesley, J.G. (2014) How Does the Quasi-Biennial Oscillation Affect the Stratospheric Polar Vortex? Journal of the Atmospheric Sciences, 71, 391-409. https://doi.org/10.1175/JAS-D-13-096.1

[61] Huang, B.H., Hu, Z.Z., Kinter, J.L., Wu, Z.H. and Kumar, A. (2012) Connection of Stratospheric QBO with Global Atmospheric General Circulation and Tropical SST. Part I: Methodology and Composite Life Cycle. Climate Dynamics, 38, 1-23. https://doi.org/10.1007/s00382-011-1250-7

[62] Rind, D. and Balachandran, N.K. (1995) Modelling the Effects of UV Variability and the QBO on the Troposphere-Stratosphere System. Part II: The Troposphere. Journal of Climate, 8, 2080-2095.

[63] Hitchman, M.H. and Huesmann, A.S. (2009) Seasonal Influence of the Quasi-Biennial Oscillation on Stratospheric Jets and Rossby Wave Breaking. Journal of the Atmospheric Sciences, 66, 935-946. https://doi.org/10.1175/2008JAS2631.1

[64] Sudo, K. and Takahashi, M. (2001) Simulation of Tropospheric Ozone Changes during 1997-1998 El Nino: Meteorological Impact on Tropospheric Photochemistry. Geophysical Research Letters, 28, 4091-4094. https://doi.org/10.1029/2001GL013335

[65] Sudo, K., Takahashi, M. and Akimoto, H. (2002) CHASER: A Global Chemical Model of the Troposphere, 2, Model Results and Evaluation. Journal of Geophysical Research, 107. https://doi.org/10.1029/2001JD001114

[66] Uppala, S.M., Kallberg, P.W., et al. (2005) The ERA-40 Re-Analysis. Quarterly Journal of the Royal Meteorological Society, 131, 2961-3012. https://doi.org/10.1256/qj.04.176

[67] Dee, D. and Uppala, S. (2009) Variational Bias Correction of Satellite Radiance Data in the ERA-Interim Reanalysis. Quarterly Journal of the Royal Meteorological Society, 135, 1830-1841. https://doi.org/10.1002/qj.493

[68] Dee, D.P., Uppala, S.M., Simmons, A.J., et al. (2011) The ERA-Interim Reanalysis: 
Configuration and Performance of the Data Assimilation System. Quarterly Journal of the Royal Meteorological Society, 137, 553-597. https://doi.org/10.1002/qj.828

[69] Dethof, A. and Holm, E. (2004) Ozone Assimilation in the ERA-40 Reanalysis Project. Quarterly Journal of the Royal Meteorological Society, 130, 2851-2872. https://doi.org/10.1256/qj.03.196

[70] Cariolle, D. and Deque, M. (1986) Southern Hemisphere Medium-Scale Waves and Total Ozone Disturbances in a Spectral General Circulation Model. Journal of Geophysical Research, 91, 10825-10846. https://doi.org/10.1029/JD091iD10p10825

[71] Cariolle, D. and Teyssendre, H. (2007) A Revised Linear Ozone Photochemistry Parameterization for Use in Transport and General Circulation Models: Multi-Annual Simulations. Atmospheric Chemistry and Physics Discussion, 7, 1655-1697. https://doi.org/10.5194/acpd-7-1655-2007

[72] Dragani, R. (2011) On the Quality of the ERA-Interim Ozone Reanalyses: Comparison with Satellite Data. Quarterly Journal of the Royal Meteorological Society, 137, 1312-1326. https://doi.org/10.1002/qj.821

[73] Simmons, A., Uppala, S. and Dee, D. (2007) Update on ERA-Interim. ECMWF Newsletter, 111, 5 .

[74] Uppala, S., Dee, D., Kobayashi, S., Berrisford, P. and Simmons, A. (2008) Towards a Climate Data Assimilation System: Status Update of ERA-Interim. ECMWF Newsletter, 115, 12-18.

[75] Graystone, P. (1959) Meteorological Office Discussion on Tropical Meteorology. Met Magazine, 88, 117.

[76] Schirber, S. (2015) Influence of ENSO on the QBO: Results from an Ensemble of Idealized Simulations. Journal of Geophysical Research: Atmospheres, 120, 1109-1122. https://doi.org/10.1002/2014JD022460

[77] Hansen, F., Matthes, K. and Wahl, S. (2016) Tropospheric QBO-ENSO Interactions and Differences between the Atlantic and Pacific. Journal of Climate, Journal of Geophysical Research: Atmospheres, 29, 1353-1368. https://doi.org/10.1175/JCLI-D-15-0164.1

[78] Hsu, J. and Prather, M.J. (2014) Is the Residual Vertical Velocity a Good Proxy for Stratosphere-Troposphere Exchange of Ozone? Geophysical Research Letters, 41, 9024-9032. https://doi.org/10.1002/2014GL061994 